\title{
Simulation and Real Time Implementation of Various PWM Strategies for $3 \Phi$ Multilevel Inverter Using FPGA
}

\author{
C. R. Balamurugan ${ }^{1}$, S. P. Natarajan ${ }^{2}$, T. S. Anandhi ${ }^{3}$, B. Shanthi ${ }^{4}$ \\ ${ }^{1}$ Department of Electrical and Electronics Engineering, Arunai Engg. College, India \\ ${ }^{2,3,4}$ Department of ElE, Annamalai University, Chidambaram, India
}

\section{Article Info \\ Article history: \\ Received Jan 2, 2017 \\ Revised Jan 21, 2017 \\ Accepted Feb 12, 2017}

\section{Keywords:}

CMLI

Crest factor

Form factor

PWM

THD

VRMS

\begin{abstract}
For high power applications Multilevel Inverter (MLI) is extensively used. The major advantages of MLI are good power quality, low switching losses and maintenance of the desired voltage. In this work, the three phase cascaded multi level inverter is analyzed under various modulation techniques that include Sub-Harmonic Pulse Width Modulation (SHPWM) i.e. Phase Disposition (PD) strategy, Phase Opposition Disposition (POD) strategy, Alternate Phase Opposition Disposition (APOD) strategy, hybrid strategy (PD and PS) and Phase Shift (PS) strategy. The study will help to choose those techniques with reduced harmonics for the chosen three phase cascaded MLI with R-L load. The Total Harmonic Distortion (THD), VRMS (fundamental), crest factor and form factor are evaluated for various modulation indices at two different switching frequencies $(3.15 \mathrm{KHz}$ and 6 $\mathrm{KHz}$ ). Simulation is performed using MATLAB-SIMULINK. It is observed that HYBRID PWM and PSPWM methods provide output with relatively low distortion for low and high switching frequencies. PODPWM and PSPWM are found to perform better since they provide relatively higher fundamental RMS output voltage for $6 \mathrm{KHz}$ and $3.15 \mathrm{KHz}$ switching frequencies. The experimental result shows PSPWM provide output with low distortion and HYBRID PWM provide output with higher fundamental RMS voltage for $\mathrm{fc}=3.15 \mathrm{KHz}$. The experimental results were obtained only for $\mathrm{fc}=3.15 \mathrm{KHz}$.
\end{abstract}

Copyright (C) 2017 Institute of Advanced Engineering and Science. All rights reserved.

\section{Corresponding Author:}

C. R. Balamurugan,

Department of Electrical and Electronics Engineering,

Arunai Engineering College,

Tiruvannamalai, India.

Email: crbalain2010@gmail.com

\section{INTRODUCTION}

Multilevel inverters offer a number of advantages when compared to its conventional two-level inverter counterpart. The stepped approximation of the sinusoidal output using higher levels reduces the harmonic distortion of the output and the stresses across the semiconductor devices and also allows higher voltage/current and power ratings. Rajesh Gupta et al [1] proposed switching characterization of cascaded multilevel inverter controlled systems. Palanivel and Dash [2] evaluated THD and output voltage of three phase cascaded MLI using multicarrier PWM techniques. Rajesh Gupta et al [3] developed multiband hysteresis modulation and switching characterization for sliding-mode-controlled cascaded MLI. Ghoreishy et al [4] proposed methods for reducing common-mode voltage and power dissipation in cascaded multilevel inverters with flexible DC sources. Malinowski et al [5] carried out a detailed survey on cascaded multilevel inverters. Zhong et al [6] discussed fundamental frequency switching strategies of a seven level hybrid cascaded H-bridge multilevel inverter. Teodorescu et al [7] developed a multilevel inverter using cascaded industrial voltage source inverter. Corzine et al [8] proposed control for cascaded multilevel inverter. Deepa 
et al [9] undertook harmonic analysis of a modified cascaded multilevel inverter. Zambra et al [10] Compared neutral point clamped, symmetrical and hybrid asymmetrical multilevel inverters. Youheihinago and Hirotaka Koizumi [11] proposed a single phase multilevel inverter using switched series/parallel DC voltage sources. Risnidar et al [12] discusses the influence of harmonics in laboratory due to Nonlinear Loads. Mohammad Jamil in [13] made a comparison on multilevel inverters with reduction of common mode voltage. Manjunatha and Anand [14] suggested a multilevel DC link inverter with reduced switches and batteries. Balamurugan et al [15] introduced a new bipolar hybrid carrier PWM strategies for symmetrical multi level inverter. Balamurugan et al [16] made a comparison between simulation and dSPACE based implementation of various PWM strategies for a new H-type FCMLI topology. This literature survey reveals few papers only on various PWM techniques and hence this work presents a novel approach for controlling the harmonics of output voltage of chosen MLI employing sinusoidal PWM switching strategies with triangular carriers. Simulations are performed using MATLAB-SIMULINK. Harmonics analysis and evaluation of performance measures for various modulation indices have been carried out and presented.

\section{MULTILEVEL INVERTER}

The multilevel inverters have drawn tremendous interest in the power industry. Multilevel inverters are also well suited for use in reactive power compensation. Power electronics technologies have also provided an important improvement of renewable energy applications. Many renewable energy applications will require high power inverters $(>50 \mathrm{~kW})$; for instance, a grid connected inverter. Therefore, multilevel inverters are suitable for this application because a multilevel inverter can possibly provide the high volt ampere ratings; multilevel inverters will significantly reduce the magnitude of harmonics and increases the output voltage and power without the use of step-up transformer. A cascaded multilevel inverter consists of a series of $\mathrm{H}$ - bridge inverter units connected to three phase R-L load. The general function of this multilevel inverter is to synthesize a desired voltage from several DC sources. The AC terminal voltages of each bridge are connected in series. Unlike the diode clamped or flying-capacitors inverter, the cascaded inverter does not require any voltage clamping diodes. This configuration is useful for constant frequency applications such as active front- end rectifiers, active power filters, and reactive power compensation. In this case, one of the very efficiently used control strategies is the space vector based control, which can be implemented using digital signal processor. Fig. 1 shows the three phase cascaded multilevel inverter with induction motor load. The general function of this multilevel inverter is to produce a preferred voltage from several separate DC sources, which may be obtained from batteries, fuel cells or solar cells. Each DC source is connected to an Hbridge inverter. The operation of cascaded multilevel inverter is based on the separate DC sources. Each inverter level can generate three different voltage outputs, $+\mathrm{V}_{\mathrm{dc}}, 0$ and $-\mathrm{V}_{\mathrm{dc}}$ using various combinations of four switches. The number of output phase voltage levels $\mathrm{m}$ in a cascaded inverter is defined by $\mathrm{m}=2 \mathrm{~s}+1$, where $s$ is the number of separate DC sources. Using the example, turning on $T_{a 1}$ and $T_{a 4}$ yields $+V_{d c}$ output voltage, turning on $\mathrm{T}_{\mathrm{a} 2}$ and $\mathrm{T}_{\mathrm{a} 3}$ yields $-\mathrm{V}_{\mathrm{dc}}$ output voltage, turning off all switches yields no output. Fig. 1 show the power circuit of three phase cascaded multilevel inverter. The AC output voltage at other bridges can be obtained in the same manner. Controlling the conducting periods of switches of different inverter bridges can minimize the harmonic distortion of the output voltage. Several forms of renewable zero pollution energy resources including wind, solar, bio, geothermal can be used by cascaded multilevel inverter.



Figure 1. A three phase cascaded multilevel inverter 


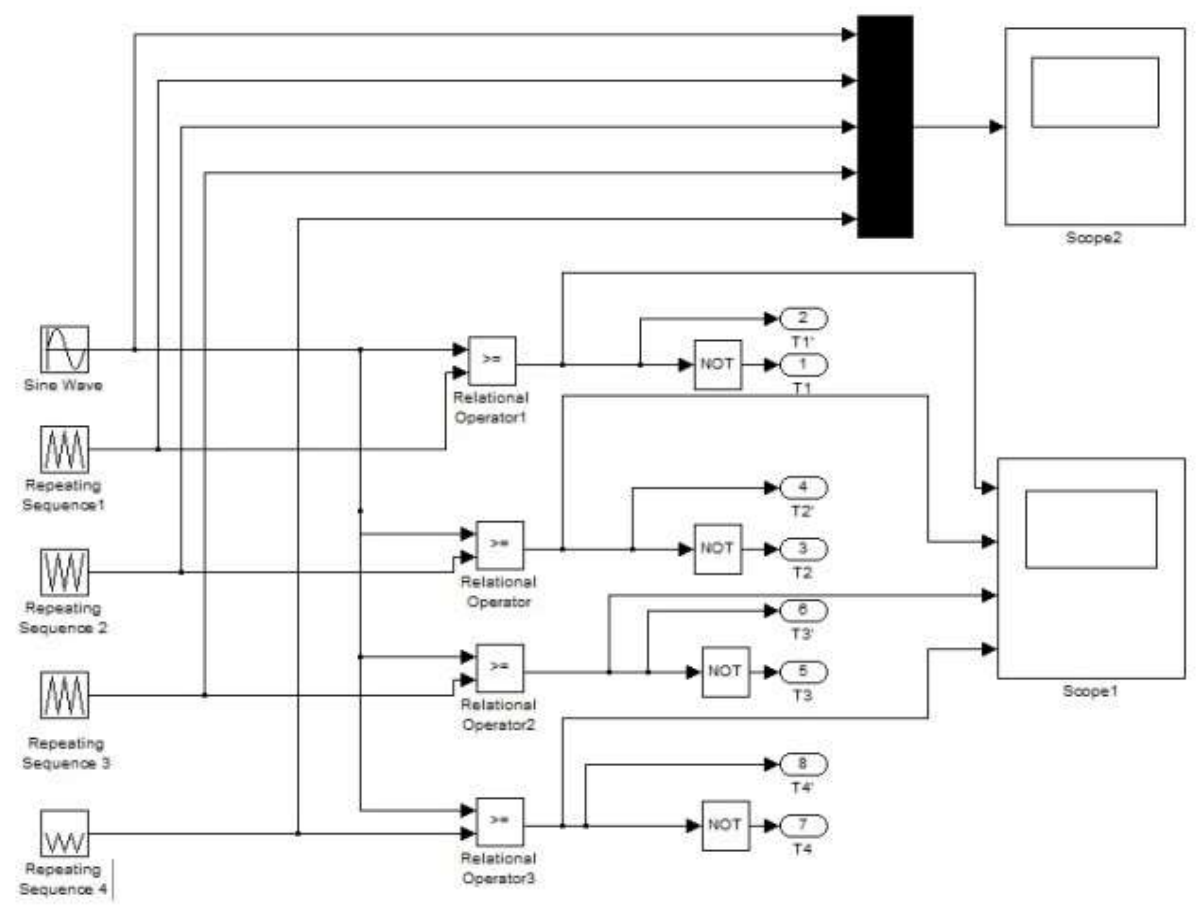

Figure 2. Sample PWM generation logic using SIMULINK developed for APOD TECHNIQUE

\section{MULTICARRIER PWM METHODS}

This work used the intersection of a sine wave reference signal with triangular carrier waves to generate firing pulses. There are five alternative strategies to implement this objective and Figure 2 shows a sample PWM generation logic.

\subsection{Phase Disposition PWM Strategy}

The rules for phase disposition method Figures (3 and 4) for a multilevel inverter are

a. 4 carrier waveforms in phase are arranged.

b. The converter is switched to $+2 \mathrm{Vdc}$ when the sine wave is greater than both upper carrier waveform.

c. The converter is switched to $+\mathrm{Vdc}$ when the sine wave is greater than first upper carrier waveform.

d. The converter is switched to zero when sine wave is lower than upper carrier but higher than the lower carrier.

e. The converter is switched to - Vdc when the sine wave is less than first lower carrier waveform.

f. The converter is switched to $-2 \mathrm{Vdc}$ when the sine wave is less than both lower carrier waveforms.

The following formula is applicable to sub harmonic PWM strategy i.e PD, POD and APOD PWMs.

The frequency modulation index is

The amplitude modulation index is

$$
\begin{aligned}
& \mathrm{m}_{\mathrm{f}}=\mathrm{f}_{\mathrm{c}} / \mathrm{f}_{\mathrm{m}} \\
& \mathrm{m}_{\mathrm{a}}=2 \mathrm{~A}_{\mathrm{m}} /(\mathrm{m}-1) \mathrm{A}_{\mathrm{c}}
\end{aligned}
$$

where

$f_{c}-$ Frequency of the carrier signal

$f_{m}-$ Frequency of the reference signal

$A_{m}$ - Amplitude of the reference signal

$A_{c}-$ Amplitude of the carrier signal

$m$ - Number of levels. 


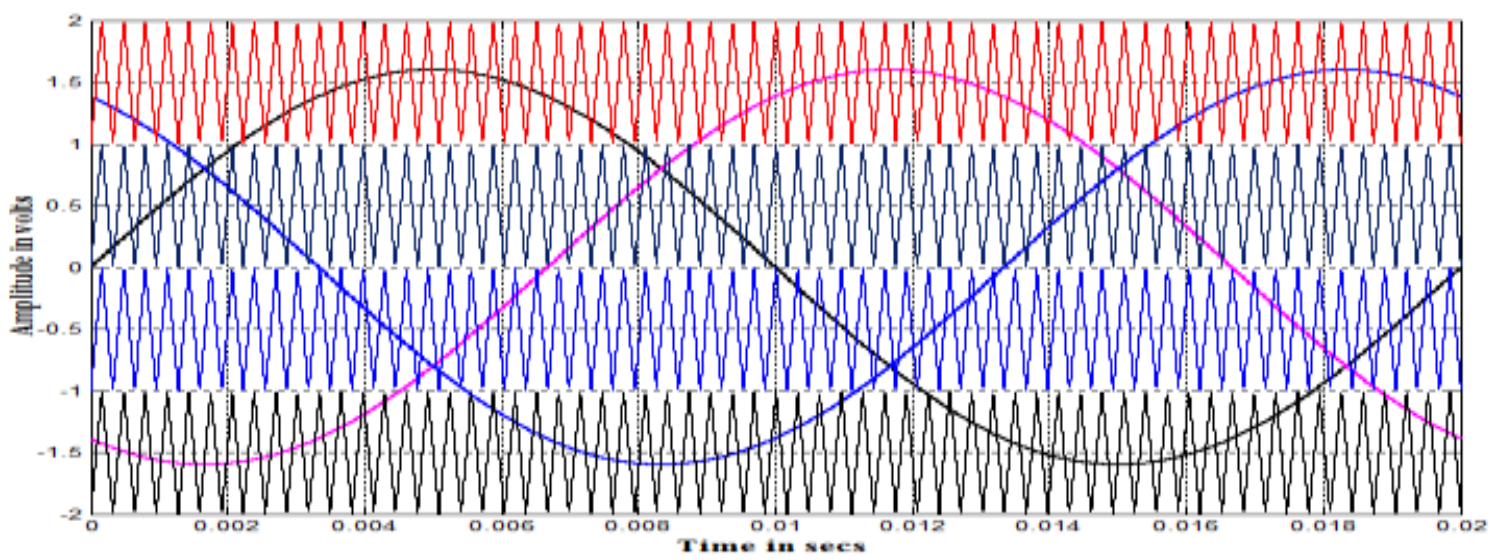

Figure 3. Carrier Arrangement for PDPWM Strategy $\left(\mathrm{m}_{\mathrm{a}}=0.8\right.$ and $\left.\mathrm{m}_{\mathrm{f}}=63\right)$

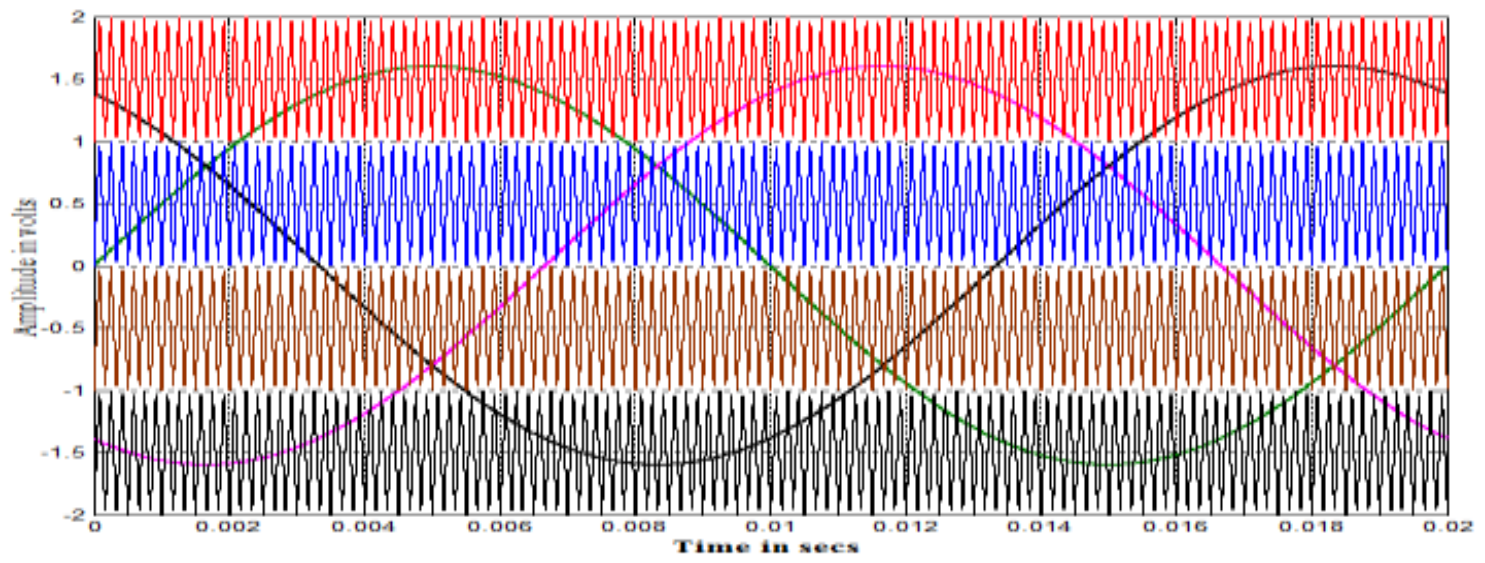

Figure 4. Carrier arrangement for PDPWM strategy $\left(\mathrm{m}_{\mathrm{a}}=0.8\right.$ and $\left.\mathrm{m}_{\mathrm{f}}=120\right)$

\subsection{Phase Opposition and Disposition PWM Strategy}

Four carrier waveforms are arranged so that all carrier waveforms above zero are in phase and they are 180 degrees out of phase with those below zero see Figures 5 and 6.

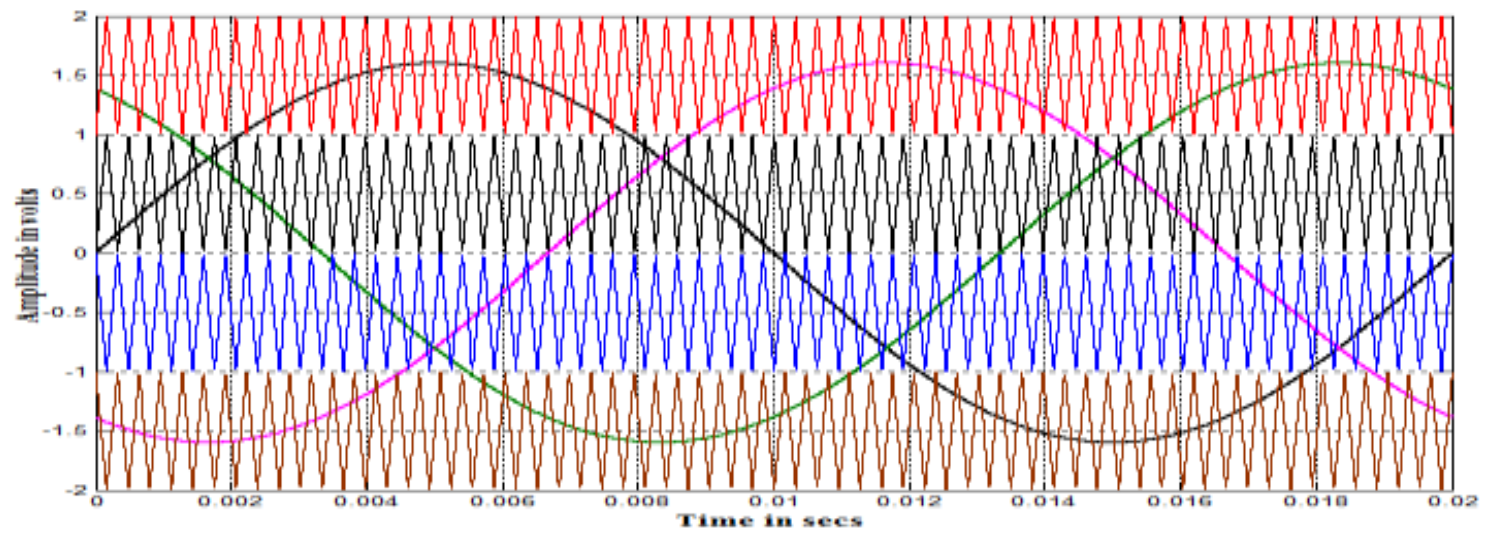

Figure 5. Carrier arrangement for PODPWM strategy $\left(\mathrm{m}_{\mathrm{a}}=0.8 \mathrm{~m}_{\mathrm{f}}=63\right)$ 


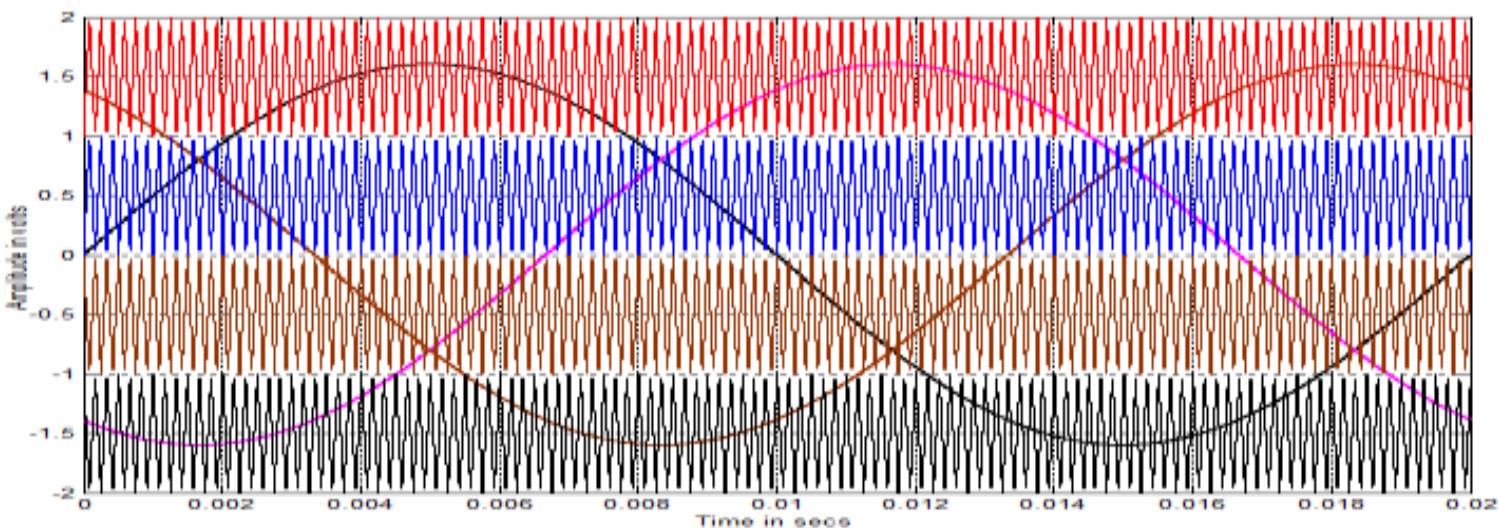

Figure 6. Carrier arrangement for PODPWM strategy $\left(\mathrm{m}_{\mathrm{a}}=0.8\right.$ and $\left.\mathrm{m}_{\mathrm{f}}=120\right)$

\subsection{Alternative Phase Opposition and Disposition PWM strategy}

Carriers are arranged in such a manner that each carrier is out of phase with its neighbor by 180 degrees see Figure 7 and 8.

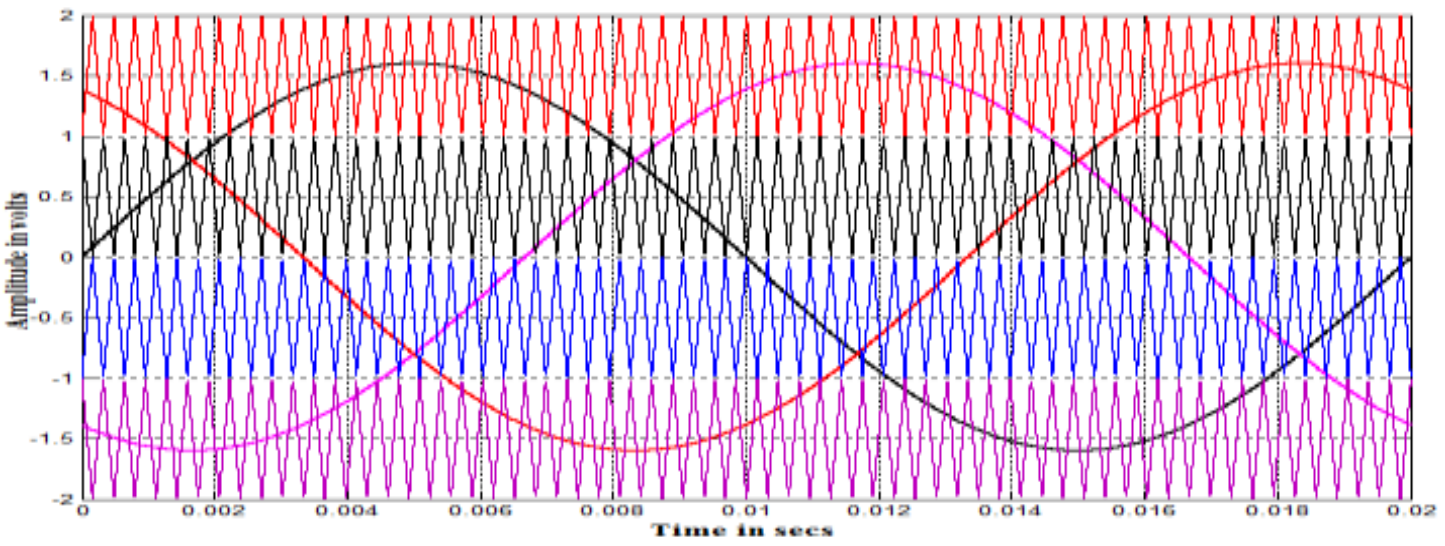

Figure 7. Carrier arrangement for APODPWM strategy $\left(\mathrm{m}_{\mathrm{a}}=0.8\right.$ and $\left.\mathrm{m}_{\mathrm{f}}=63\right)$

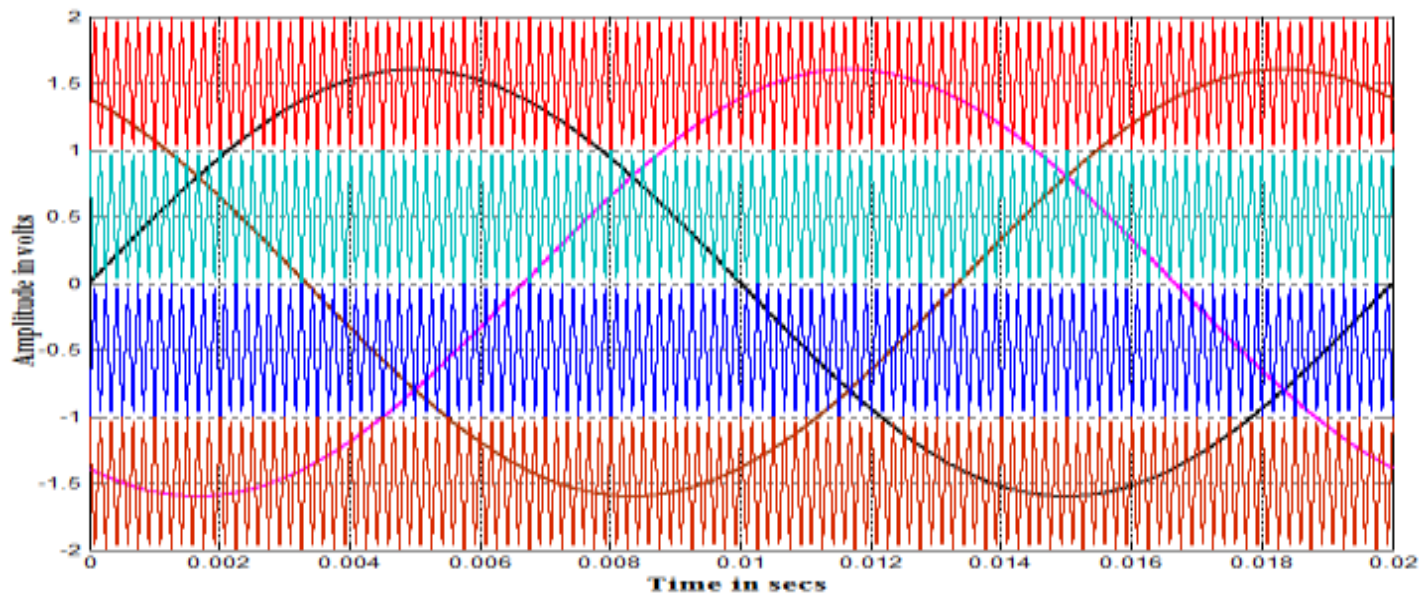

Figure 8. Carrier arrangement for APODPWM strategy $\left(\mathrm{m}_{\mathrm{a}}=0.8\right.$ and $\left.\mathrm{m}_{\mathrm{f}}=120\right)$ 


\subsection{Phase Shift PWM Strategy}

The phase shift multicarrier PWM technique uses four carrier signals of the same amplitude and frequency which are shifted by 90 degrees to one another to generate the five level inverter output voltages see Figure 9 and 10. The gate signals for the cascaded inverter can be derived directly from the PWM signals (comparison of the carrier with the sinusoidal reference). There is a certain degree of freedom in the allocation of the carriers to the inverter switches.

The amplitude modulation index

$$
\mathrm{m}_{\mathrm{a}}=\mathrm{A}_{\mathrm{m}} /\left(\mathrm{A}_{\mathrm{c}} / 2\right)
$$

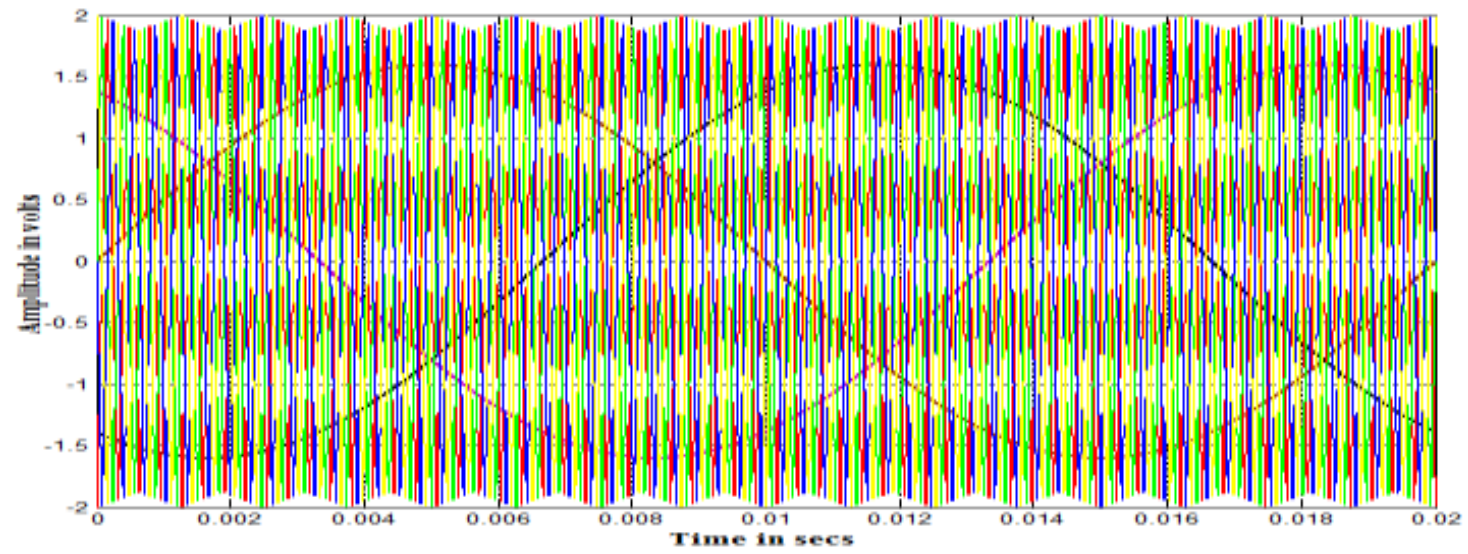

Figure 9. Carrier arrangement for PSPWM strategy $\left(\mathrm{m}_{\mathrm{a}}=0.8\right.$ and $\left.\mathrm{m}_{\mathrm{f}}=63\right)$

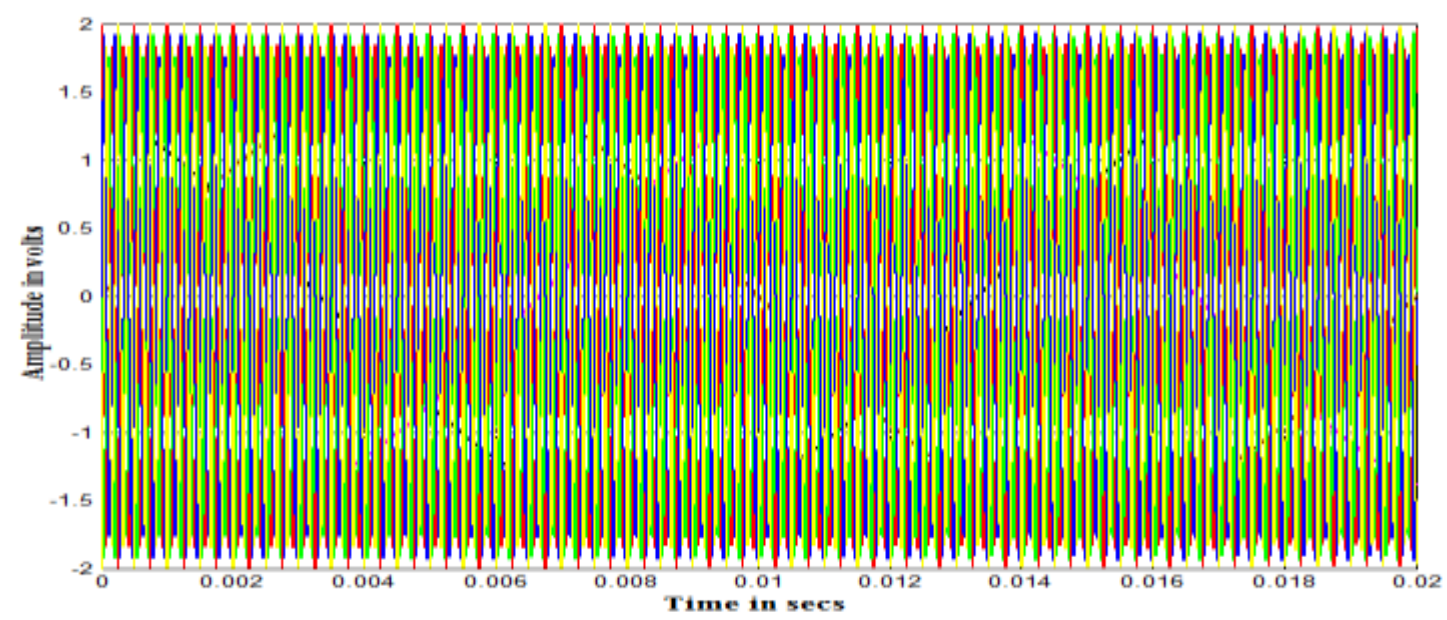

Figure 10. Carrier arrangement for PSPWM strategy $\left(\mathrm{m}_{\mathrm{a}}=0.8\right.$ and $\left.\mathrm{m}_{\mathrm{f}}=120\right)$

\subsection{Hybrid PWM Strategy}

The hybrid PWM strategy is the combination of phase disposition and phase shift strategy. Hybrid PWM strategy is illustrated see Figure 11 and 12. 


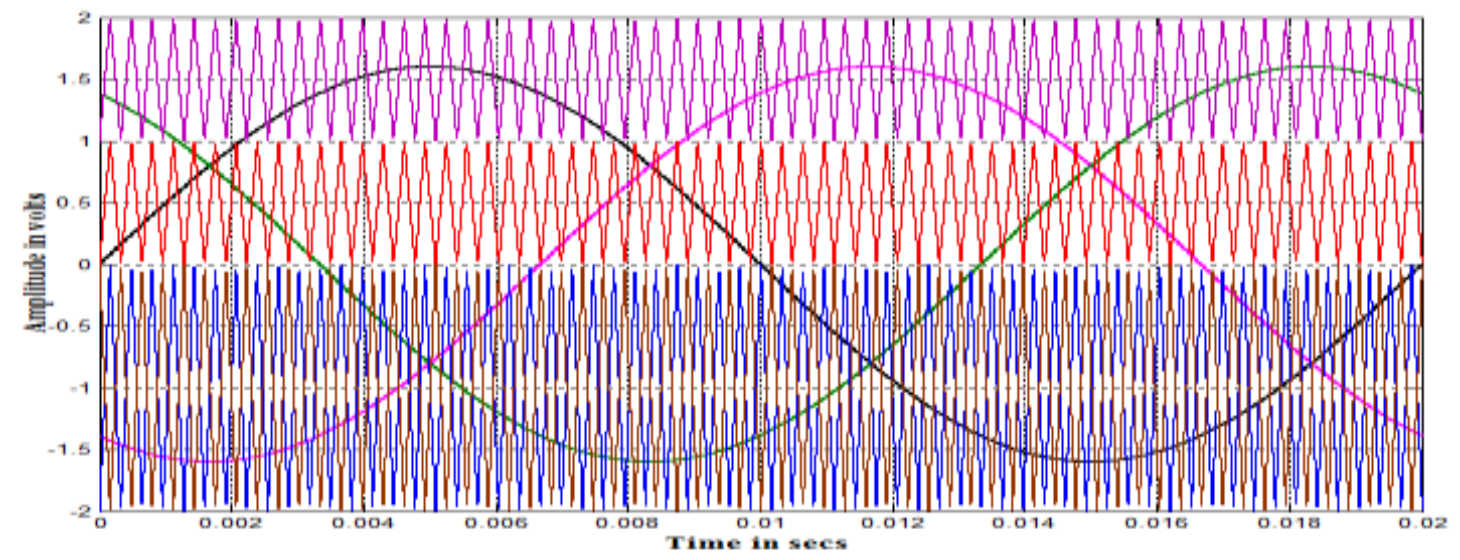

Figure 11. Carrier arrangement for HYBRID PWM strategy $\left(\mathrm{m}_{\mathrm{a}}=0.8\right.$ and $\left.\mathrm{m}_{\mathrm{f}}=63\right)$

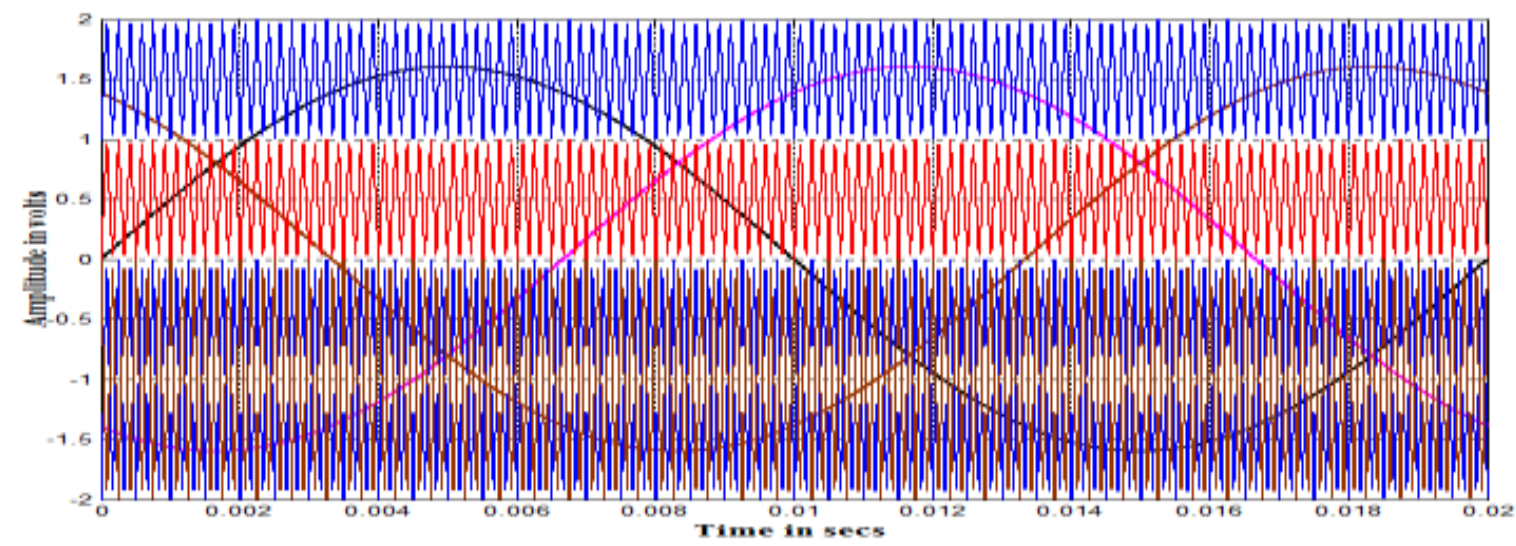

Figure 12. Carrier arrangement for HYBRID PWM strategy $\left(\mathrm{m}_{\mathrm{a}}=0.8\right.$ and $\left.\mathrm{m}_{\mathrm{f}}=120\right)$

\section{SIMULATION RESULTS}

To verify the proposed schemes, a simulation model for a three phase five level cascaded H-bridge inverter is implemented using MATLAB as in Figure 2. Simulations are performed for different values of $m_{a}$ ranging from 0.5 to 0.9 and the corresponding \% THD is measured using the FFT block and their values are shown in Table 1. Figures 13 - 32 show the simulated output voltages of CMLI and their harmonic spectrum with different PWM strategies but for only one sample value of $\mathrm{m}_{\mathrm{a}=0.8}$ for R-L load. Figure 13 shows the five level output voltage generated by PDPWM strategy $\left(m_{\mathrm{f}}=63\right.$ with $\mathrm{f}_{\mathrm{c}}=3.15 \mathrm{KHz}$ and $\left.\mathrm{f}_{\mathrm{m}}=50 \mathrm{~Hz}\right)$ and its FFT plot is shown in Figure 14. From Figure 14 it is observed that the PDPWM strategy produces significant $53^{\text {rd }}$, $55^{\text {th }}, 59^{\text {th }}$ and $61^{\text {st }}$ harmonic energy. Figure 15 shows the five level output voltage generated by PDPWM strategy $\left(m_{\mathrm{f}}=120\right.$ with $\mathrm{f}_{\mathrm{c}}=6 \mathrm{KHz}$ and $\left.\mathrm{f}_{\mathrm{m}}=50 \mathrm{~Hz}\right)$ and its FFT plot is shown in Figure 16. From Figure 16 it is observed that the PDPWM strategy produces significant $110^{\text {th }}, 112^{\text {th }}, 116^{\text {th }}$ and $118^{\text {th }}$ harmonic energy. Figure 17 shows the five level output voltage generated by PODPWM strategy $\left(\mathrm{f}_{\mathrm{c}}=3.15 \mathrm{KHz}\right)$ and its FFT plot is shown in Figure 18. From Figure 18 it is observed that the PODPWM strategy produces significant $56^{\text {th }}, 58^{\text {th }}$ and $62^{\text {nd }}$ harmonic energy. Figure 19 shows the five level output voltage generated by PODPWM strategy $\left(f_{c}=6 \mathrm{KHz}\right)$ and its FFT plot is shown in Figure 20. From Figure 20 it is observed that the PODPWM strategy produces significant $114^{\text {th }}, 116^{\text {th }}$ and $120^{\text {th }}$ harmonic energy. Figure 21 shows the five level output voltage generated by APODPWM strategy $\left(f_{c}=3.15 \mathrm{KHz}\right)$ and its FFT plot is shown in Figure 22. From Figure 22 it is observed that the APODPWM strategy produces significant $58^{\text {th }}, 60^{\text {th }}$ and $62^{\text {nd }}$ harmonic energy. Figure 23 shows the five level output voltage generated by APODPWM strategy $\left(\mathrm{f}_{\mathrm{c}}=6 \mathrm{KHz}\right)$ and its FFT plot is shown in Figure 24. From Figure 24 it is observed that the APODPWM strategy produces significant $116^{\text {th }}, 118^{\text {th }}$ and $120^{\text {th }}$ harmonic energy. Figure 25 shows the five level output voltage generated by HYBRIDPWM strategy $\left(f_{c}=3.15 \mathrm{KHz}\right)$ and its FFT plot is shown in Figure 26. From Figure 26 it is observed that the HYBRIDPWM strategy produces significant $53^{\text {rd }}, 55^{\text {th }}, 56^{\text {th }}, 58^{\text {th }}$ and $62^{\text {nd }}$ harmonic energy. Figure 27 shows the five level output voltage generated by HYBRIDPWM strategy $\left(\mathrm{f}_{\mathrm{c}}=6 \mathrm{KHz}\right)$ and its FFT plot is shown in 
Figure 28. From Figure 28 it is observed that the HYBRIDPWM strategy produces significant $113^{\text {th }}, 114^{\text {th }}$, $116^{\text {th }}$ and $120^{\text {th }}$ harmonic energy. Figure 29 shows the five level output voltage generated by PSPWM strategy $\left(f_{c}=3.15 \mathrm{KHz}\right)$ and its FFT plot is shown in Figure 30. From Figure 30 it is observed that the PSPWM strategy does not produce significant harmonic energy. Figure 31 shows the five level output voltage generated by PSPWM strategy $\left(f_{c}=6 \mathrm{KHz}\right)$ and its FFT plot is shown in Figure 32 . From Figure 32 it is observed that the PSPWM strategy does not produce significant harmonic energy. The following parameters were chosen for the simulation $\mathrm{V}_{\mathrm{dc}=} 20 \mathrm{~V}, \mathrm{f}_{\mathrm{c}=3} 3.15 \mathrm{KHz}$ and $6 \mathrm{KHz}, \mathrm{R}=100 \mathrm{ohms}$ and $\mathrm{L}=0.5 \mathrm{mH}$.

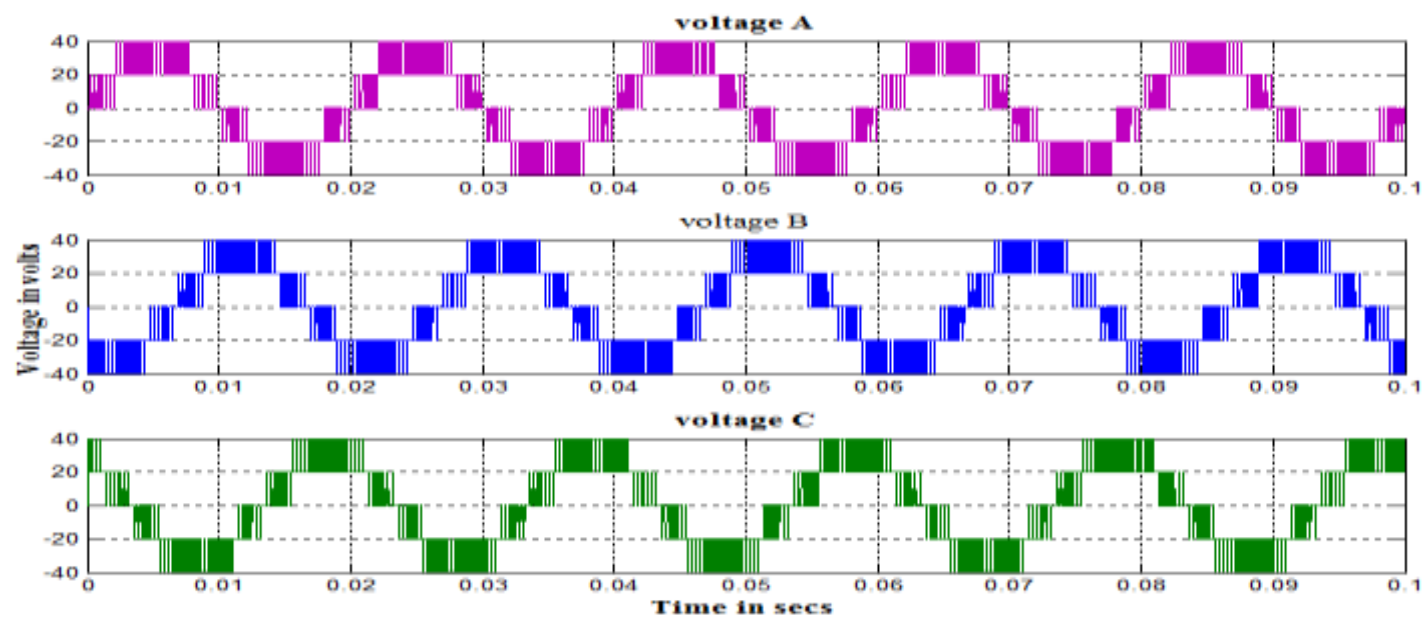

Figure 13. Output voltage generated by PDPWM strategy for R-L load. $\left(\mathrm{m}_{\mathrm{a}}=0.8\right.$ and $\left.\mathrm{m}_{\mathrm{f}}=63\right)$

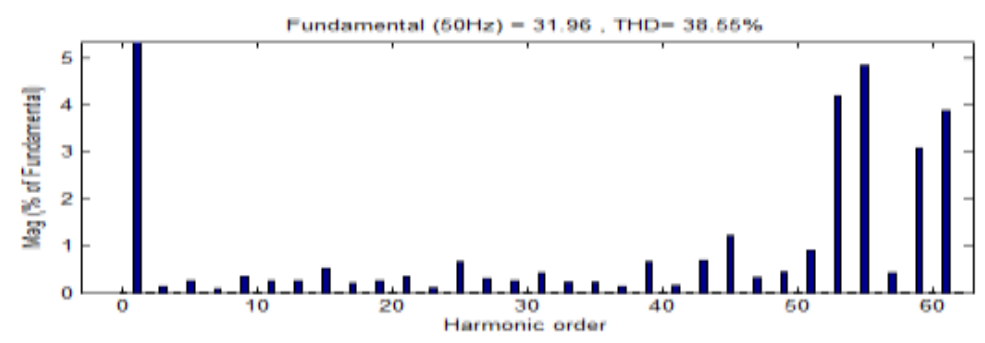

Figure 14. FFT plot for output voltage of PDPWM strategy for R-L load $\left(\mathrm{m}_{\mathrm{f}}=63\right)$

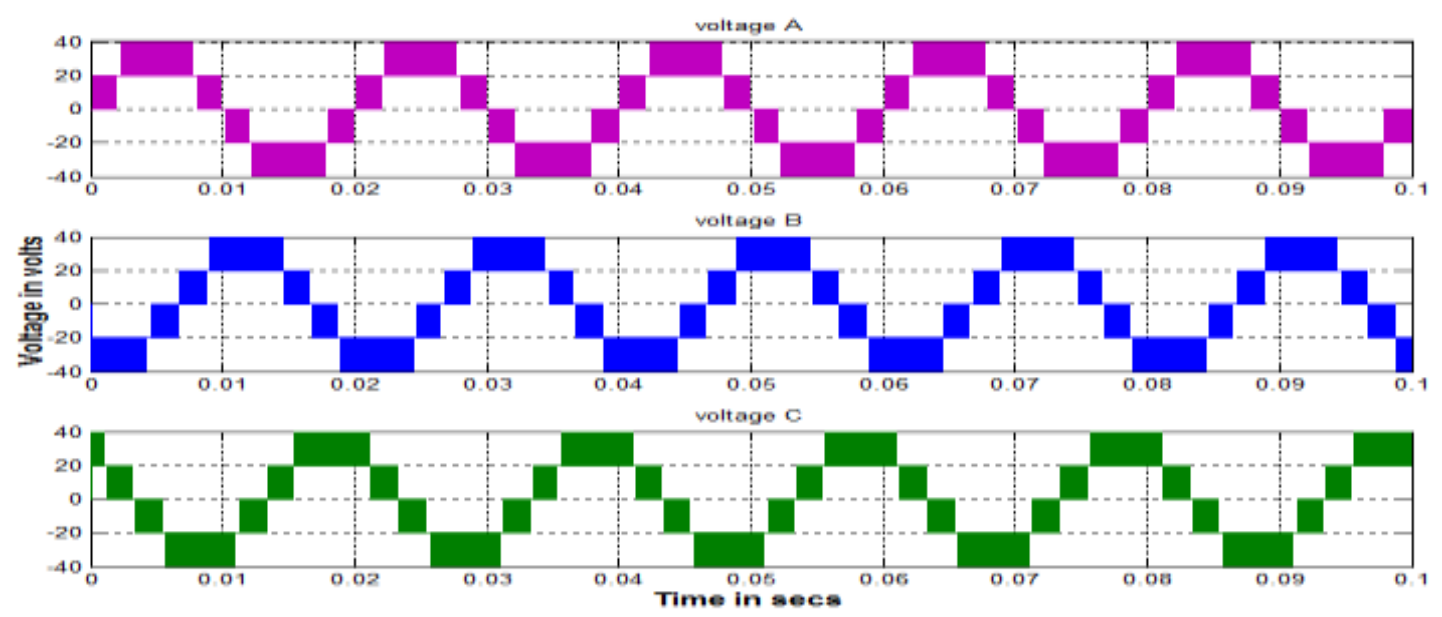

Figure 15 Output voltage generated by PDPWM strategy for R-L load $\left(\mathrm{m}_{\mathrm{a}}=0.8\right.$ and $\left.\mathrm{m}_{\mathrm{f}}=120\right)$ 


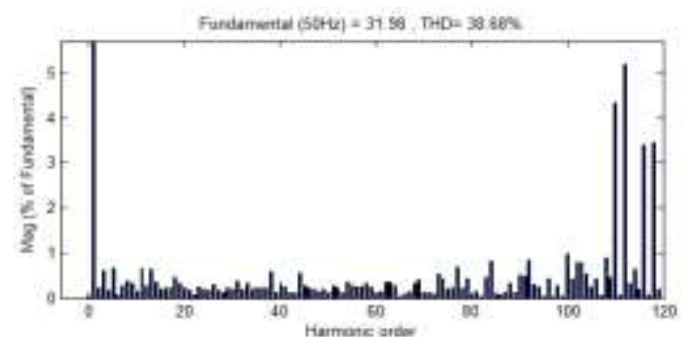

Figure 16. Output voltage generated by PDPWM strategy for R-L load $\left(\mathrm{m}_{\mathrm{f}}=120\right)$

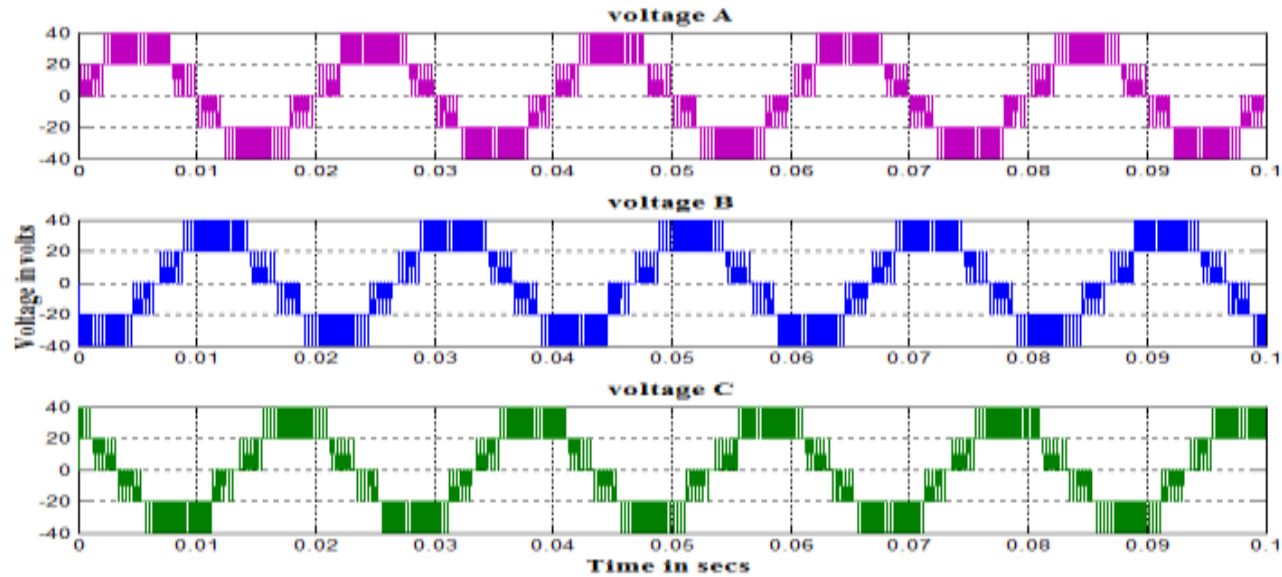

Figure 17 Output voltage generated by PODPWM Strategy for R-L load $\left(\mathrm{m}_{\mathrm{a}}=0.8\right.$ and $\left.\mathrm{m}_{\mathrm{f}}=63\right)$

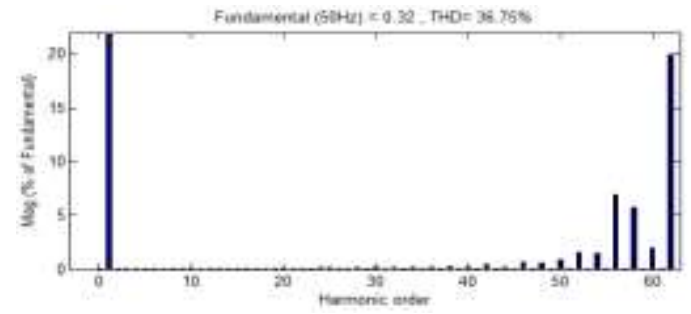

Figure 18. FFT Plot for output voltage of PODPWM strategy for R-L Load $\left(\mathrm{m}_{\mathrm{f}}=63\right)$

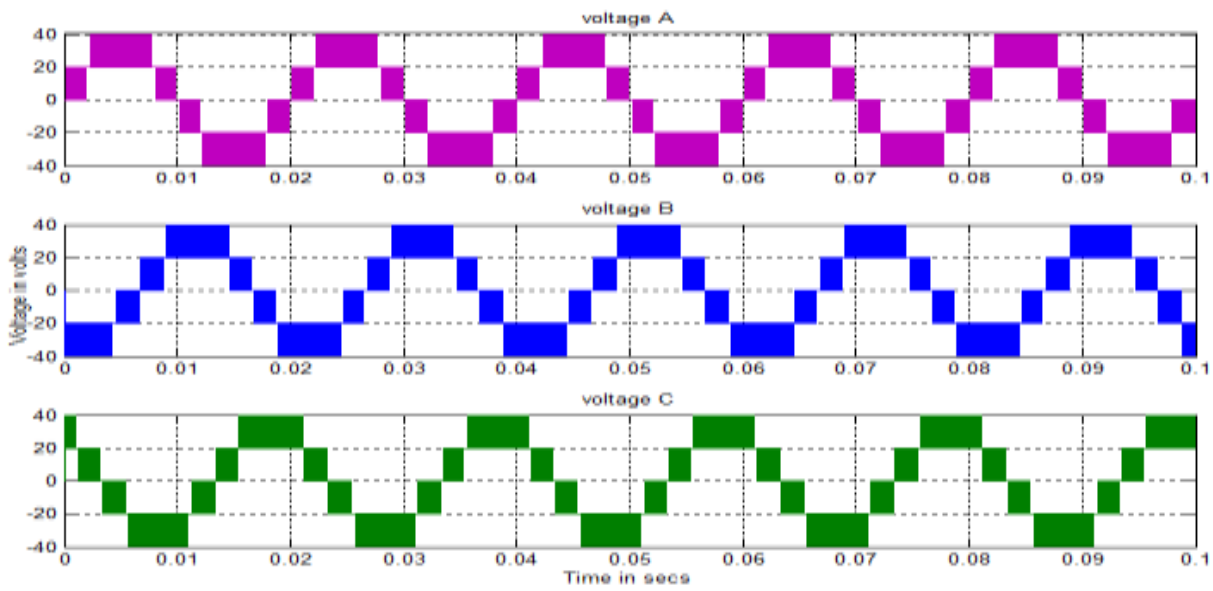

Figure 19. Output voltage generated by PODPWM Strategy for R-L Load $\left(\mathrm{m}_{\mathrm{a}}=0.8\right.$ and $\left.\mathrm{m}_{\mathrm{f}}=120\right)$ 


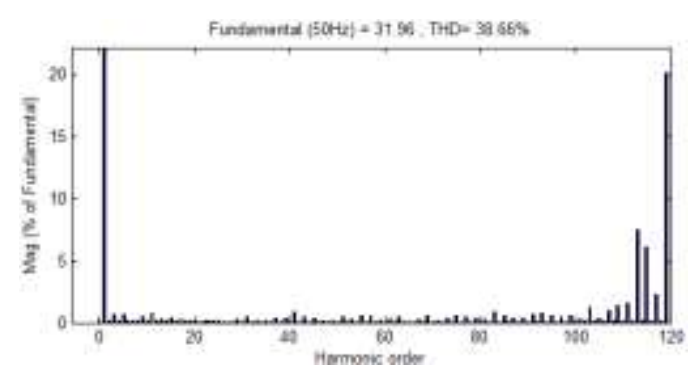

Figure 20. FFT plot for output voltage of PODPWM strategy for R-L load $\left(\mathrm{m}_{\mathrm{f}}=120\right)$

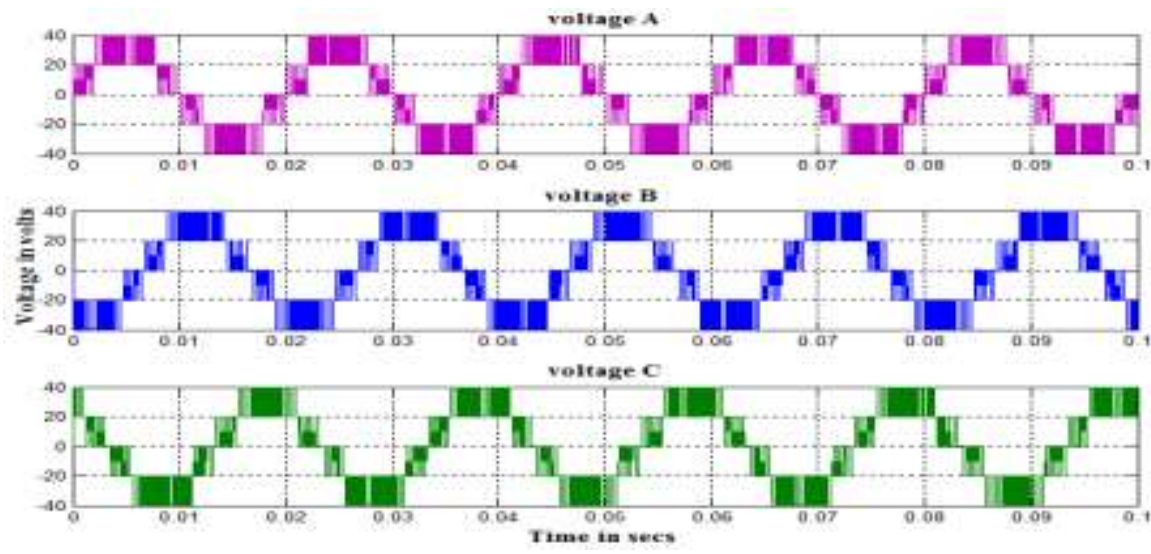

Figure 21. Output voltage generated by APODPWM strategy for R-L load $\left(\mathrm{m}_{\mathrm{a}}=0.8\right.$ and $\left.\mathrm{m}_{\mathrm{f}}=63\right)$

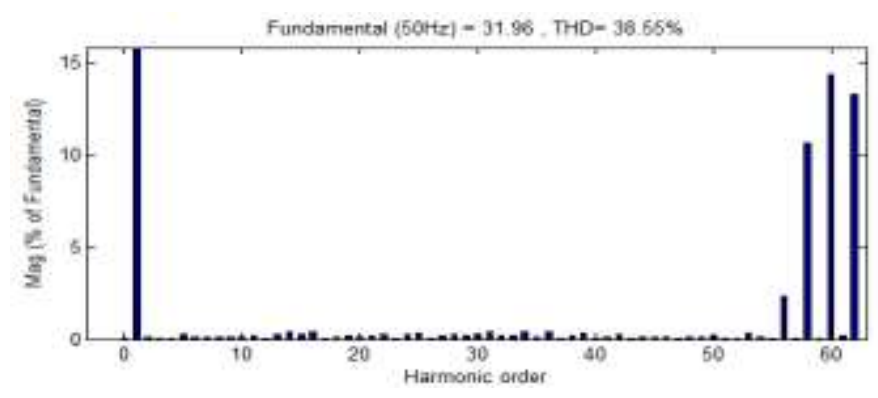

Figure 22. FFT plot for output voltage of APODPWM strategy for R-L load $\left(\mathrm{m}_{\mathrm{f}}=63\right)$

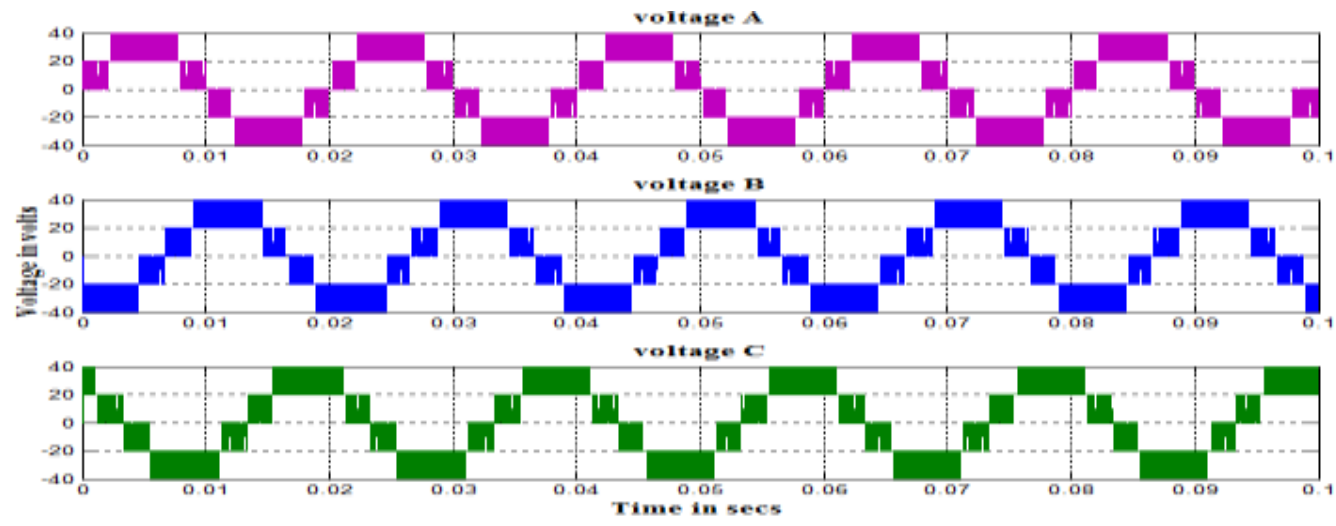

Figure 23. Output voltage generated by APODPWM strategy for R-L load $\left(\mathrm{m}_{\mathrm{a}}=0.8\right.$ and $\left.\mathrm{m}_{\mathrm{f}}=120\right)$ 


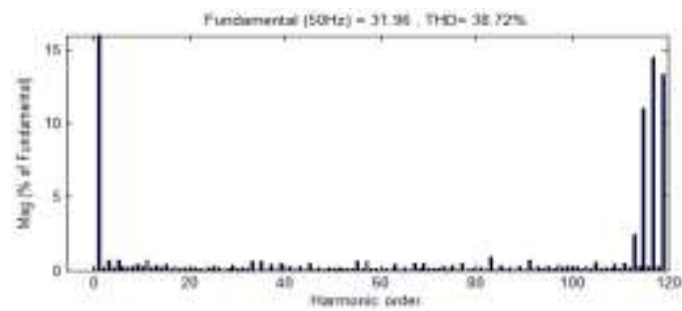

Figure 24. FFT plot for output voltage of APODPWM strategy for R-L load $\left(\mathrm{m}_{\mathrm{f}}=120\right)$

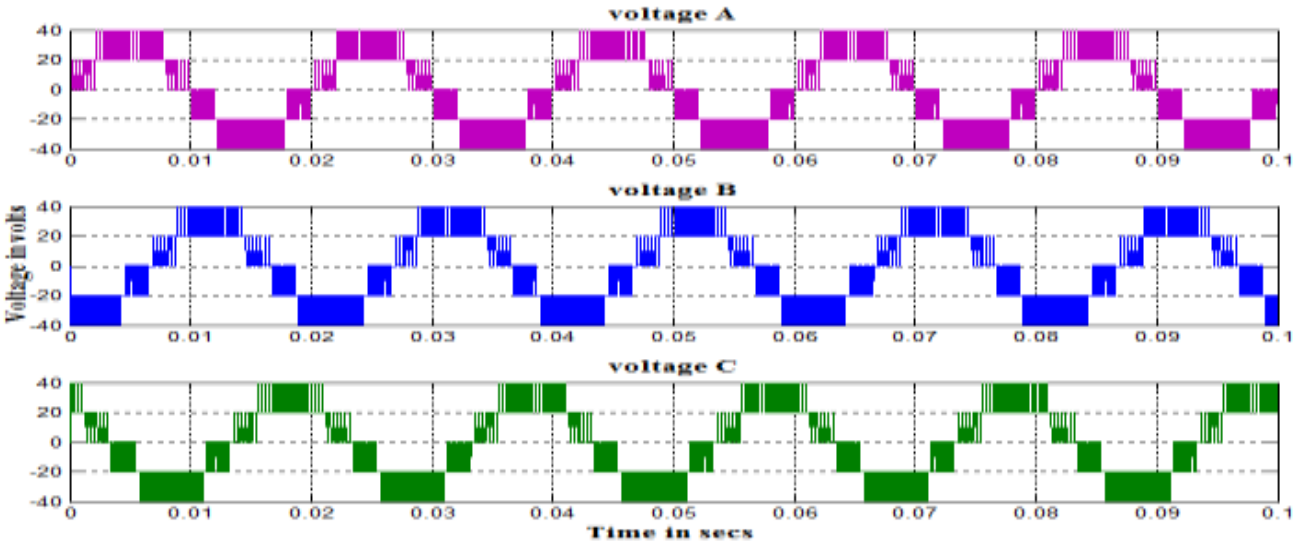

Figure 25. Output voltage generated by HYBRIDPWM strategy for R-L load $\left(\mathrm{m}_{\mathrm{a}}=0.8\right.$ and $\left.\mathrm{m}_{\mathrm{f}}=63\right)$

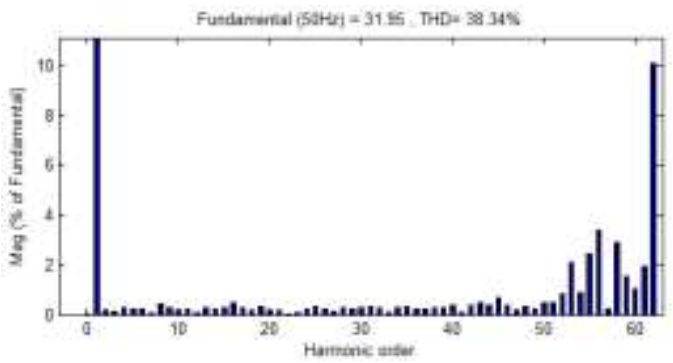

Figure 26. FFT plot for output voltage of HYBRIDPWM strategy for R-L load $\left(\mathrm{m}_{\mathrm{f}}=63\right)$
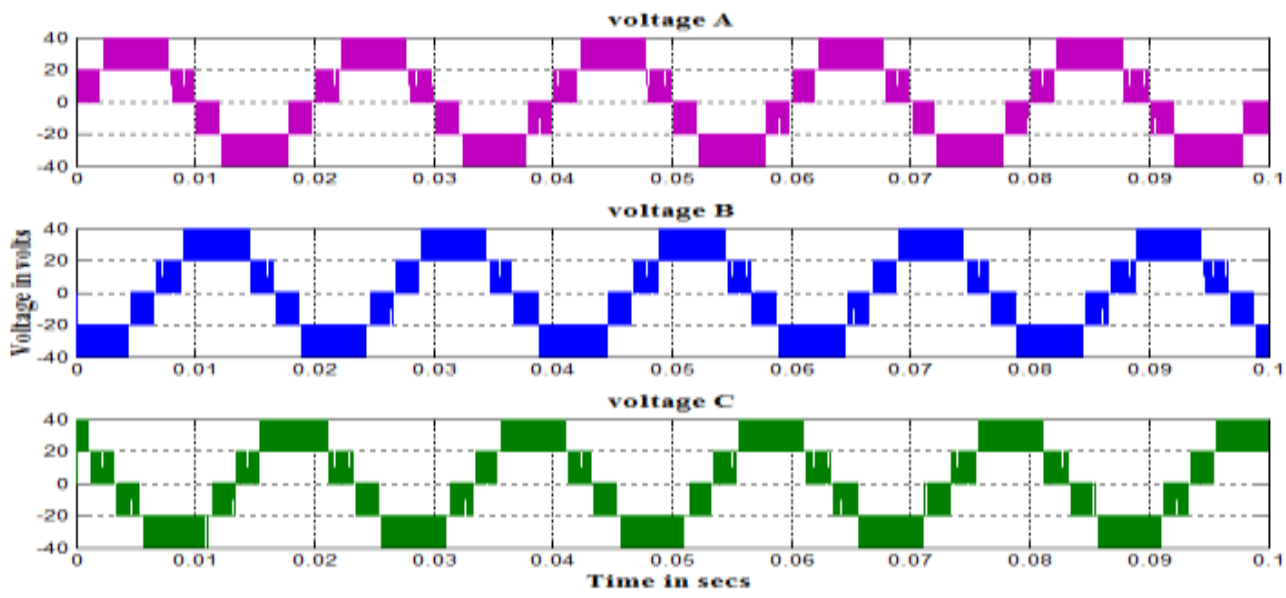

Figure 27. Output voltage generated by HYBRID PWM strategy for R-L load $\left(\mathrm{m}_{\mathrm{a}}=0.8\right.$ and $\left.\mathrm{m}_{\mathrm{f}}=120\right)$ 


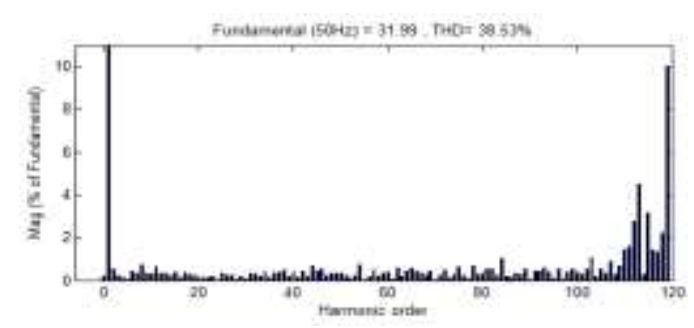

Figure 28. FFTPlot for output voltage of HYBRID PWM Strategy for R-L load $\left(\mathrm{m}_{\mathrm{f}}=120\right)$

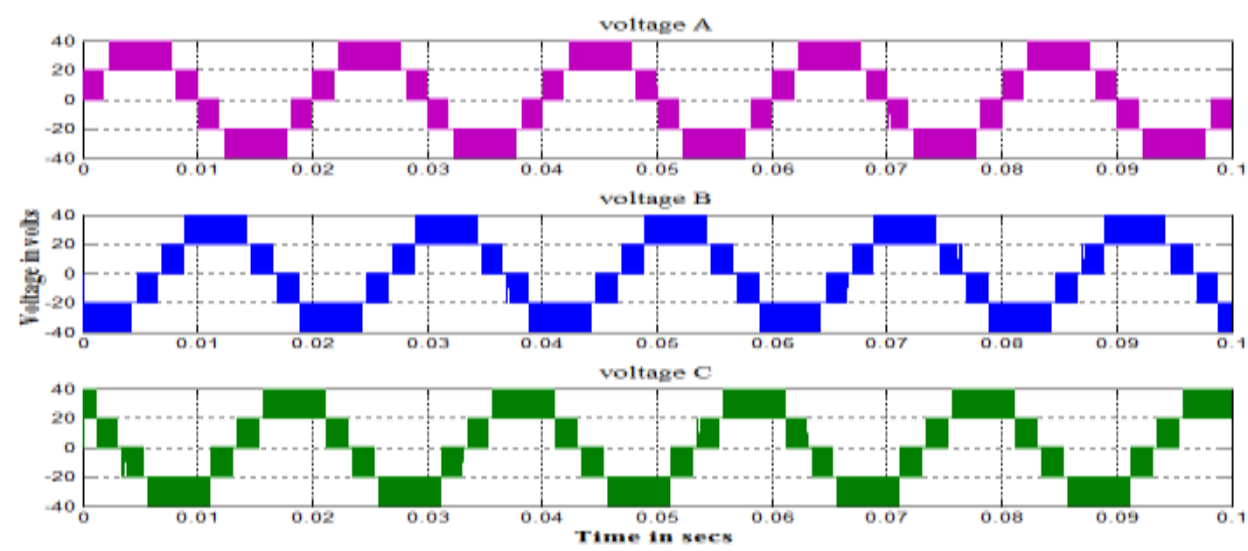

Figure 29. Output voltage generated by PSPWM strategy for R-L load $\left(\mathrm{m}_{\mathrm{a}}=0.8\right.$ and $\left.\mathrm{m}_{\mathrm{f}}=63\right)$

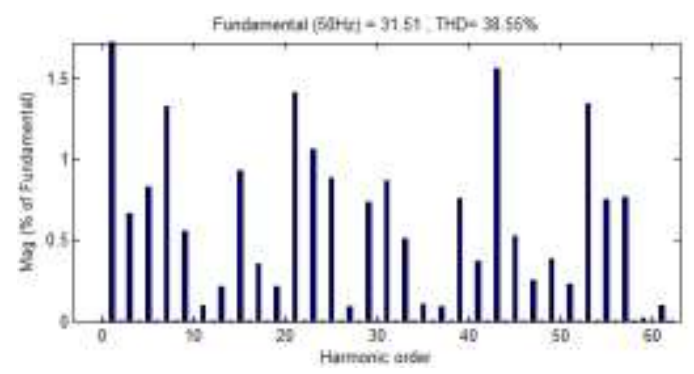

Figure 30. FFT plot for output voltage of PSPWM strategy for R-L load $\left(\mathrm{m}_{\mathrm{f}}=63\right)$

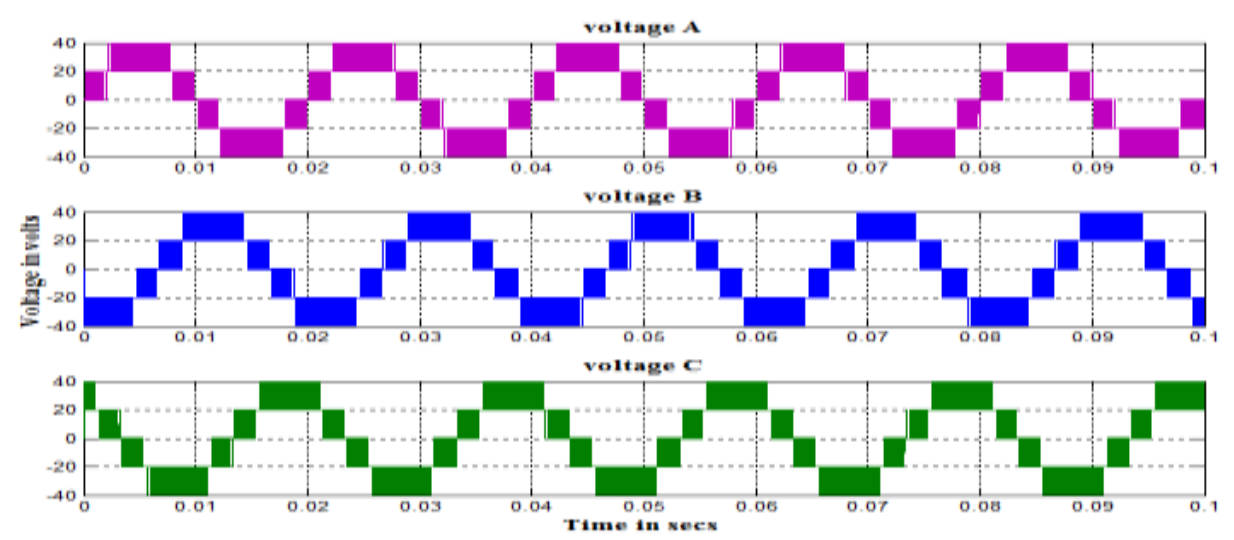

Figure 31. Output voltage generated by PSPWM strategy for R-L load $\left(\mathrm{m}_{\mathrm{a}}=0.8\right.$ and $\left.\mathrm{m}_{\mathrm{f}}=120\right)$ 


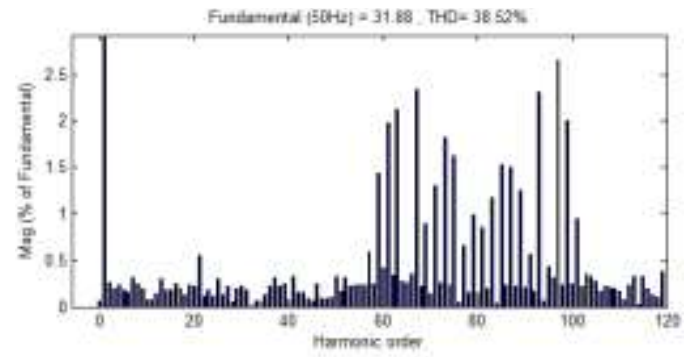

Figure 32. FFT plot for output voltage of PSPWM strategy for R-L load $\left(\mathrm{m}_{\mathrm{f}}=120\right)$

Table 1. \% THD Comparison for Different Modulation Indices with R-L Load (by Simulation)

\begin{tabular}{|c|c|c|c|c|c|c|c|c|c|c|}
\hline \multirow[b]{2}{*}{$\mathrm{m}_{\mathrm{a}}$} & \multicolumn{2}{|c|}{ PD } & \multicolumn{2}{|c|}{ POD } & \multicolumn{2}{|c|}{ APOD } & \multicolumn{2}{|c|}{ PS } & \multicolumn{2}{|c|}{ HYBRID } \\
\hline & $3.15 \mathrm{KHz}$ & $6 \mathrm{KHz}$ & $3.15 \mathrm{KHz}$ & $6 \mathrm{KHz}$ & $3.15 \mathrm{KHz}$ & $6 \mathrm{KHz}$ & $3.15 \mathrm{KHz}$ & $6 \mathrm{KHz}$ & $3.15 \mathrm{KHz}$ & $6 \mathrm{KHz}$ \\
\hline 1 & 26.93 & 26.93 & 28.3 & 27.13 & 26.93 & 28.34 & 26.10 & 27.13 & 26.72 & 26.97 \\
\hline 0.9 & 33.41 & 33.51 & 33.38 & 33.58 & 33.38 & 33.68 & 33.24 & 33.43 & 33.37 & 33.52 \\
\hline 0.7 & 41.73 & 41.61 & 41.73 & 41.51 & 41.73 & 41.93 & 43.18 & 41.86 & 41.78 & 41.55 \\
\hline 0.6 & 44.43 & 44.41 & 44.43 & 44.24 & 44.43 & 44.55 & 44.37 & 44.06 & 44.19 & 44.17 \\
\hline 0.5 & 51.76 & 52.70 & 51.17 & 53.39 & 51.77 & 51.56 & 55.12 & 52.02 & 51.48 & 52.79 \\
\hline
\end{tabular}

Table 2. $\mathrm{V}_{\mathrm{RMS}}$ (Fundamental) for Different Modulation Indices for R-L Load (by Simulation)

\begin{tabular}{|c|c|c|c|c|c|c|c|c|c|c|}
\hline \multirow[b]{2}{*}{$\mathrm{m}_{\mathrm{a}}$} & \multicolumn{2}{|c|}{ PD } & \multicolumn{2}{|c|}{ POD } & \multicolumn{2}{|c|}{ APOD } & \multicolumn{2}{|c|}{ PS } & \multicolumn{2}{|c|}{ HYBRID } \\
\hline & $3.15 \mathrm{KHz}$ & $6 \mathrm{KHz}$ & $3.15 \mathrm{KHz}$ & $6 \mathrm{KHz}$ & $3.15 \mathrm{KHz}$ & $6 \mathrm{KHz}$ & $3.15 \mathrm{KHz}$ & $6 \mathrm{KHz}$ & $3.15 \mathrm{KHz}$ & $6 \mathrm{KHz}$ \\
\hline 0.9 & 25.41 & 25.52 & 25.42 & 25.48 & 25.41 & 25.49 & 25.45 & 25.54 & 25.42 & 25.47 \\
\hline 0.7 & 19.87 & 19.81 & 19.87 & 19.92 & 19.87 & 19.86 & 20 & 19.85 & 19.86 & 19.85 \\
\hline 0.6 & 17.03 & 16.96 & 17.03 & 17 & 17.03 & 16.95 & 17.13 & 16.94 & 16.93 & 16.95 \\
\hline 0.5 & 14.19 & 14.09 & 14.19 & 14.03 & 14.19 & 14.19 & 13.84 & 14.15 & 14.24 & 14.08 \\
\hline
\end{tabular}

Table 3. Crest Factor for Different Modulation Indices with R-L Load (by Simulation)

\begin{tabular}{|c|c|c|c|c|c|c|c|c|c|c|}
\hline \multirow[b]{2}{*}{$\mathrm{m}_{\mathrm{a}}$} & \multicolumn{2}{|c|}{ PD } & \multicolumn{2}{|c|}{ POD } & \multicolumn{2}{|c|}{ APOD } & \multicolumn{2}{|c|}{ PS } & \multicolumn{2}{|c|}{ HYBRID } \\
\hline & $3.15 \mathrm{KHz}$ & $6 \mathrm{KHz}$ & $3.15 \mathrm{KHz}$ & $6 \mathrm{KHz}$ & $3.15 \mathrm{KHz}$ & $6 \mathrm{KHz}$ & $3.15 \mathrm{KHz}$ & $6 \mathrm{KHz}$ & $3.15 \mathrm{KHz}$ & $6 \mathrm{KHz}$ \\
\hline 0.9 & 1.4140 & 1.4141 & 1.4145 & 1.4139 & 1.4142 & 1.4141 & 1.4144 & 1.4139 & 1.4145 & 1.4144 \\
\hline 0.7 & 1.4139 & 1.4140 & 1.4142 & 1.4140 & 1.4141 & 1.4140 & 1.4141 & 1.4144 & 1.4145 & 1.4143 \\
\hline 0.6 & 1.4139 & 1.4139 & 1.4142 & 1.4144 & 1.4139 & 1.4144 & 1.4142 & 1.4155 & 1.4142 & 1.4139 \\
\hline 0.5 & 1.4136 & 1.4141 & 1.4144 & 1.4141 & 1.4136 & 1.4145 & 1.4144 & 1.4142 & 1.4144 & 1.4141 \\
\hline
\end{tabular}

\begin{tabular}{ccccccccccc}
\hline \multirow{2}{*}{$\mathrm{m}_{\mathrm{a}}$} & \multicolumn{2}{c}{ PD } & \multicolumn{2}{c}{ POD } & \multicolumn{2}{c}{ APOD } & \multicolumn{2}{c}{ PS } & \multicolumn{2}{c}{ HYBRID } \\
& $3.15 \mathrm{KHz}$ & $6 \mathrm{KHz}$ & $3.15 \mathrm{KHz}$ & $6 \mathrm{KHz}$ & $3.15 \mathrm{KHz}$ & $6 \mathrm{KHz}$ & $3.15 \mathrm{KHz}$ & $6 \mathrm{KHz}$ & $3.15 \mathrm{KHz}$ & $6 \mathrm{KHz}$ \\
\hline 1 & INF & 236.0 & INF & INF & INF & 1417 & INF & 122.6 & 566.8 \\
0.9 & 847 & 318.8 & INF & 849.3 & INF & 424.8 & INF & 182.4 & INF & 181.9 \\
0.8 & INF & 753.6 & INF & 251.11 & INF & 376.6 & INF & 375.6 & 53 & 119 \\
0.7 & INF & 61.90 & INF & 498 & INF & INF & INF & 180.45 & 110.33 & 79.4 \\
0.6 & INF & 130.46 & INF & 425 & INF & 423.7 & 428.25 & 211.7 & 51.30 & 99.70 \\
0.5 & INF & 46.96 & INF & 140.3 & INF & INF & INF & 283 & 40.68 & 46.93 \\
\hline
\end{tabular}

Table 4. Form Factor for Different Modulation Indices with R-L Load (by Simulation)

Table 5. Distortion Factor for Different Modulation Indices with R-L Load (by Simulation)

\begin{tabular}{ccccccccccc}
\hline \multirow{2}{*}{$\mathrm{m}_{\mathrm{a}}$} & \multicolumn{2}{c}{$\mathrm{PD}$} & \multicolumn{2}{c}{ POD } & \multicolumn{2}{c}{ APOD } & \multicolumn{2}{c}{ PS } & \multicolumn{2}{c}{ HYBRID } \\
& $3.15 \mathrm{KHz}$ & $6 \mathrm{KHz}$ & $3.15 \mathrm{KHz}$ & $6 \mathrm{KHz}$ & $3.15 \mathrm{KHz}$ & $6 \mathrm{KHz}$ & $3.15 \mathrm{KHz}$ & $6 \mathrm{KHz}$ & $3.15 \mathrm{KHz}$ & $6 \mathrm{KHz}$ \\
\hline 1 & 0.0515 & 0.0729 & 0.0678 & 0.0179 & 0.0691 & 0.0233 & 0.0324 & 0.0435 & 0.0120 & 0.176 \\
0.9 & 0.0688 & 0.0731 & 0.0136 & 0.0154 & 0.0143 & 0.0149 & 2.404 & 0.0187 & 0.0193 & 0.0324 \\
0.8 & 0.0804 & 0.0644 & 0.0157 & 0.134 & 0.0164 & 0.0151 & 0.0796 & 0.0799 & 0.0169 & 0.0157 \\
0.7 & 0.0803 & 0.0789 & 0.0164 & 0.265 & 0.0172 & 0.0188 & 0.0917 & 0.0923 & 0.0164 & 0.0175 \\
0.6 & 0.0958 & 0.0653 & 0.0165 & 0.0162 & 0.0167 & 0.0145 & 0.0714 & 0.734 & 0.0674 & 0.0165 \\
0.5 & 0.0121 & 0.0234 & 0.0197 & 0.0153 & 0.0196 & 0.0123 & 0.0622 & 0.543 & 0.423 & 0.0194 \\
\hline
\end{tabular}




\section{EXPERIMENTAL RESULTS}

This section presents the results of experimental work carried out on chosen CMLI using SPARTAN 3E development board (Model No: VPTB-05) SPARTAN-3EXC3S100E FPGA. This kit provides a low cost, easy to use development and evaluation platform for Spartan - 3E FPGA designs. Real time implementation of these strategies using FPGA requires less time for development. The Spartan-3E includes the following components and features, 100000 gates, 2160 logic cell equipment, Four $18 \mathrm{~K}$-bit block RAMs ( $72 \mathrm{~K}$ bits), Four $18 \times 18$ pipelined hardware multipliers, two digital clock managers (DCMs), 32 Mbit Intel strata flash, 3 numbers of 20 pin header to interface VLSI based experimental modules, 8 input dip switches, 8 output LEDs, on board programmable oscillator ( 3 to $200 \mathrm{MHz}$ ), 16×2 alphanumeric LCD, RS232 UART, 4 channel 8 bit 12c based ADC and single channel DAC, PS/2 keyboard/mouse, prototype area for user applications, on board configuration flash PROM XCFOIS. The gate signal generation using different PWM strategies listed above is designed and developed using VLSI software. The result of the experimental study are shown in the form of the output voltage and FFT spectrum of chosen CMLI. Optocoupler circuit provides isolator between the control circuit and the power converter circuit. The optocoupler used is $6 \mathrm{n} 137$ which is an optically coupled gate that combines a GaAsp light emitting diode and an integrated high gain photo detector. An enable input allows the detector to be strobed, The output of the detector 'IC is inversion of the applied input. The PWM signal from the FPGA are not capable of driving the MOSFETs. On order to strengthen the pulses a driver circuit is provided. The result of the experimental study are shown in the form of the oscillograms of PWM outputs and harmonic spectrum of chosen CMLI. Figs. 35-44 Show the experimental output voltage and corresponding harmonic spectrum of chosen CMLI obtained using SPARTAN-3E with PD, POD, APOD, PS and Hybrid PWM strategy respectively. The input voltage of each H-bridge is 20V. Figure 34 shows the entire hardware setup. Table. 6 and 7 Show the comparison of \% THD of output voltage with different PWM strategies for various values of modulation index.

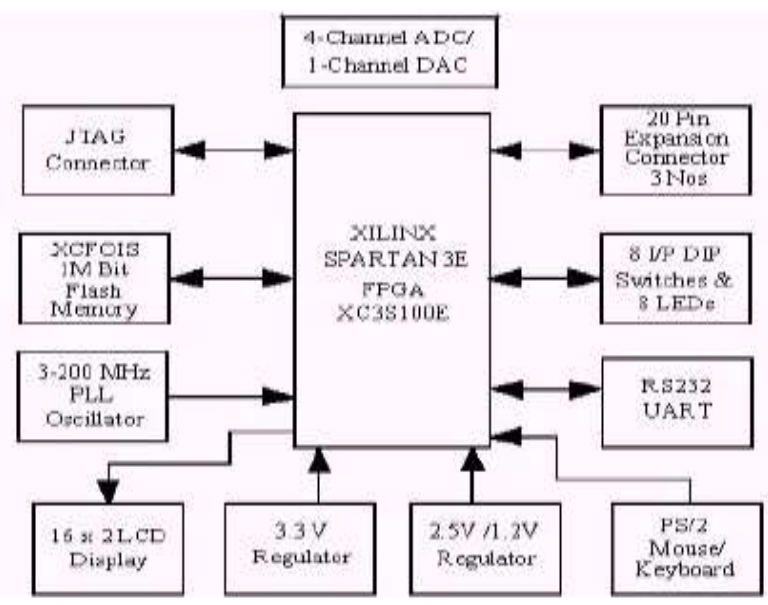

Figure 33. Spartan 3E development board block diagram

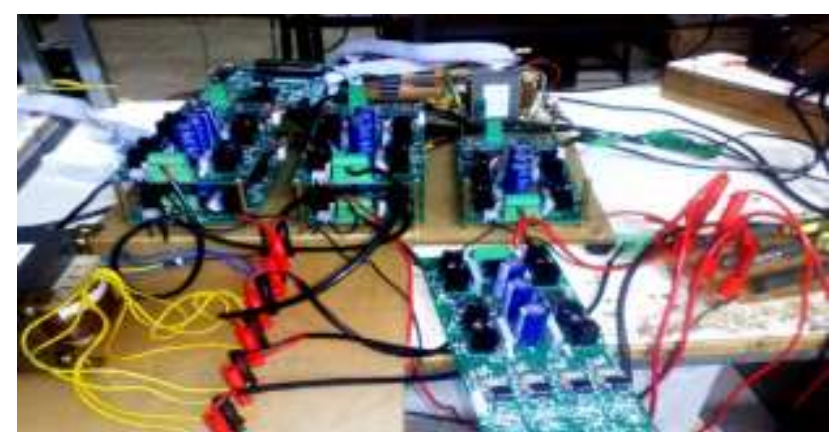

Figure 34. Entire hardware setup 


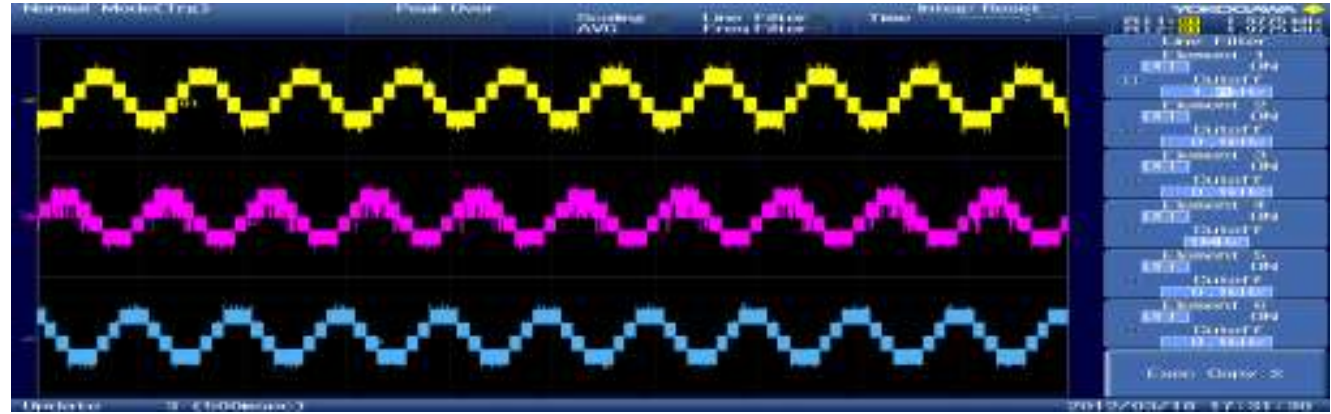

Figure 35. Output voltage generated by PDPWM strategy for R-L load. $\left(\mathrm{m}_{\mathrm{a}}=0.8\right.$ and $\left.\mathrm{m}_{\mathrm{f}}=63\right)$

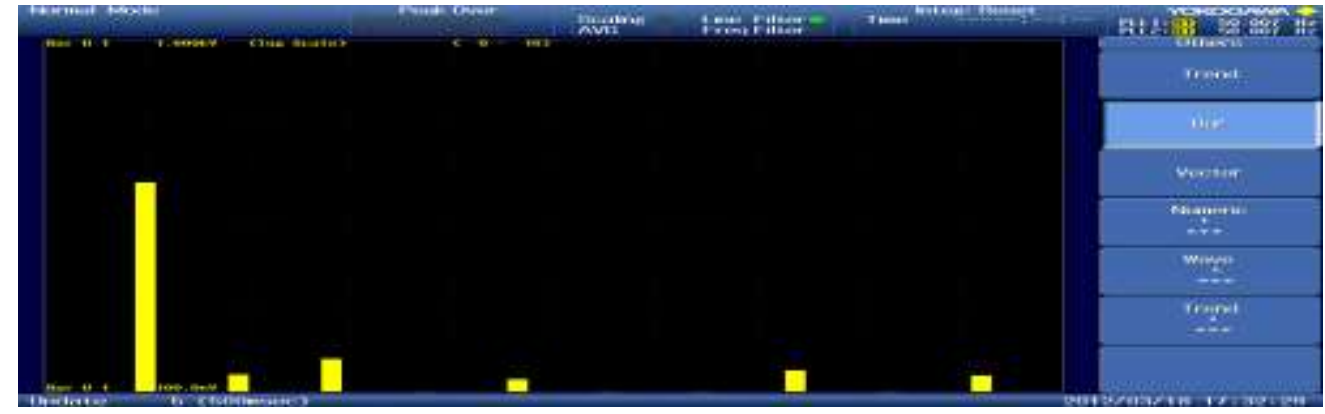

Figure 36. FFT plot for output voltage of PDPWM strategy for R-L load $\left(\mathrm{m}_{\mathrm{a}}=0.8\right.$ and $\left.\mathrm{m}_{\mathrm{f}}=63\right)$

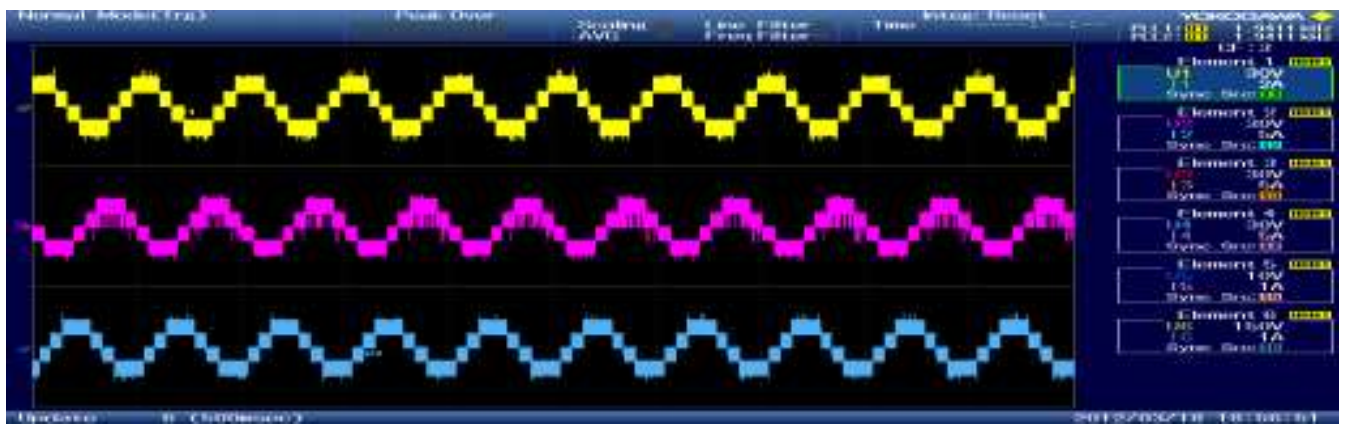

Figure 37. Output voltage generated by PODPWM strategy for R-L load. $\left(\mathrm{m}_{\mathrm{a}}=0.8\right.$ and $\left.\mathrm{m}_{\mathrm{f}}=63\right)$

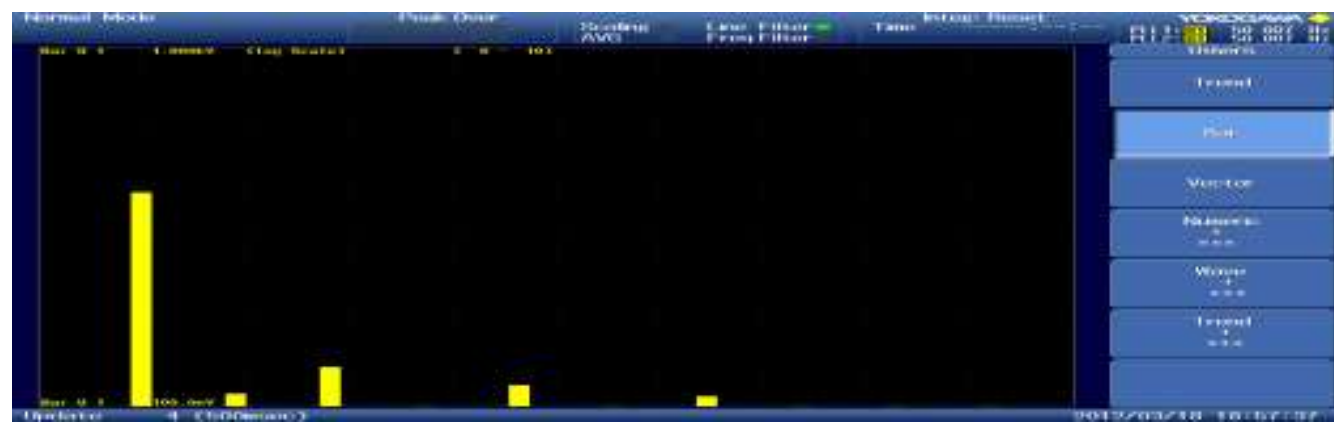

Figure 38. FFT plot for output voltage of PODPWM strategy for R-L load $\left(\mathrm{m}_{\mathrm{a}}=0.8\right.$ and $\left.\mathrm{m}_{\mathrm{f}}=63\right)$ 


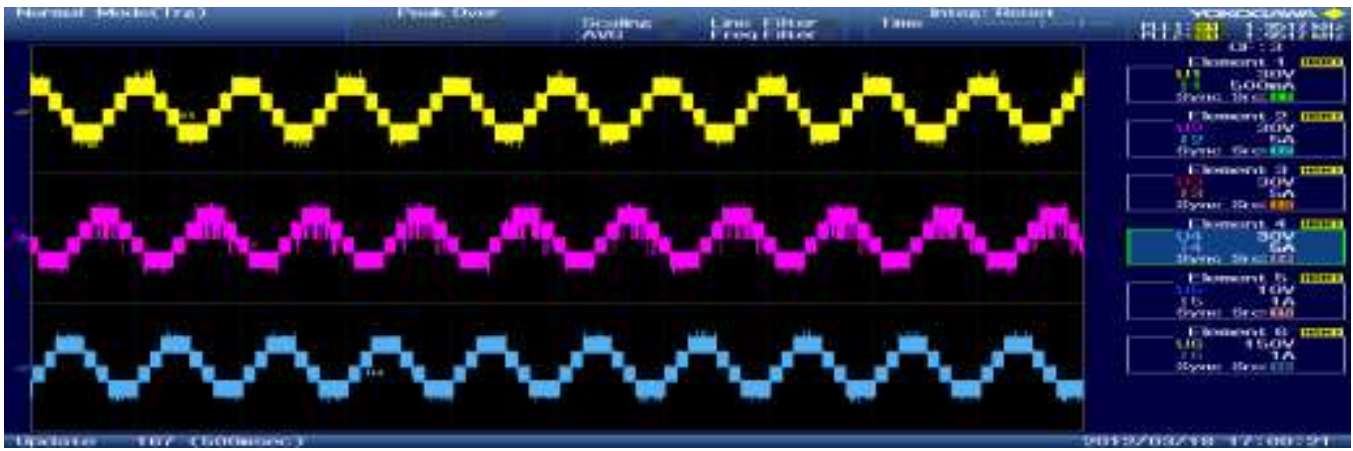

Figure 39. Output voltage generated by APODPWM strategy for R-L load. $\left(\mathrm{m}_{\mathrm{a}}=0.8\right.$ and $\left.\mathrm{m}_{\mathrm{f}}=63\right)$

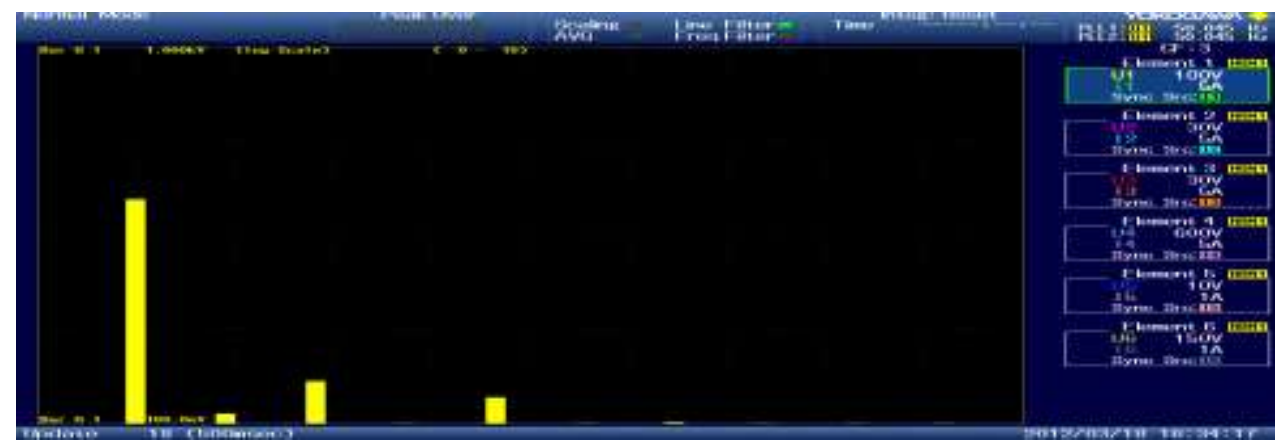

Figure 40. FFT plot for output voltage of APODPWM strategy for R-L load $\left(\mathrm{m}_{\mathrm{a}}=0.8\right.$ and $\left.\mathrm{m}_{\mathrm{f}}=63\right)$

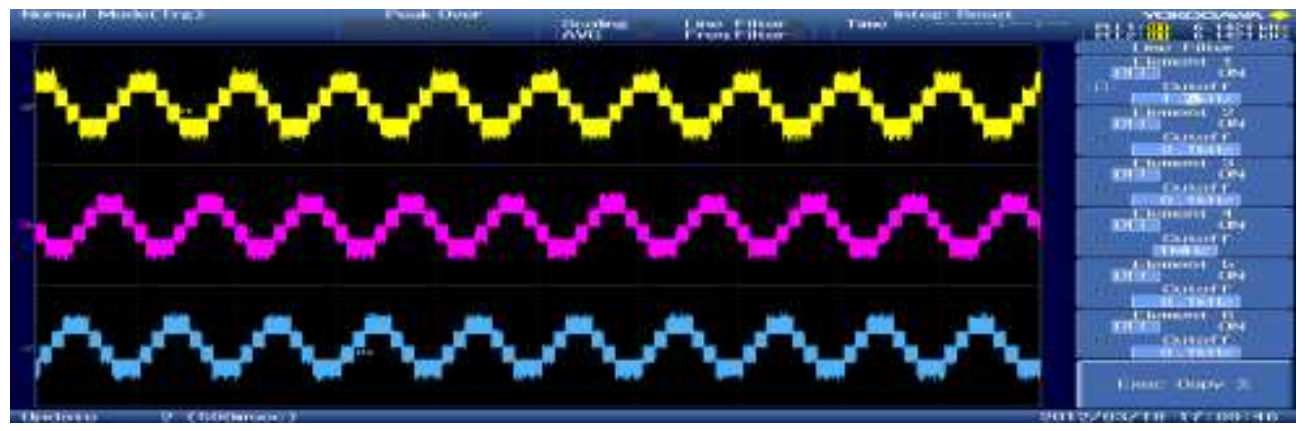

Figure 41. Output voltage generated by PSPWM strategy for R-L load. $\left(\mathrm{m}_{\mathrm{a}}=0.8\right.$ and $\left.\mathrm{m}_{\mathrm{f}}=63\right)$

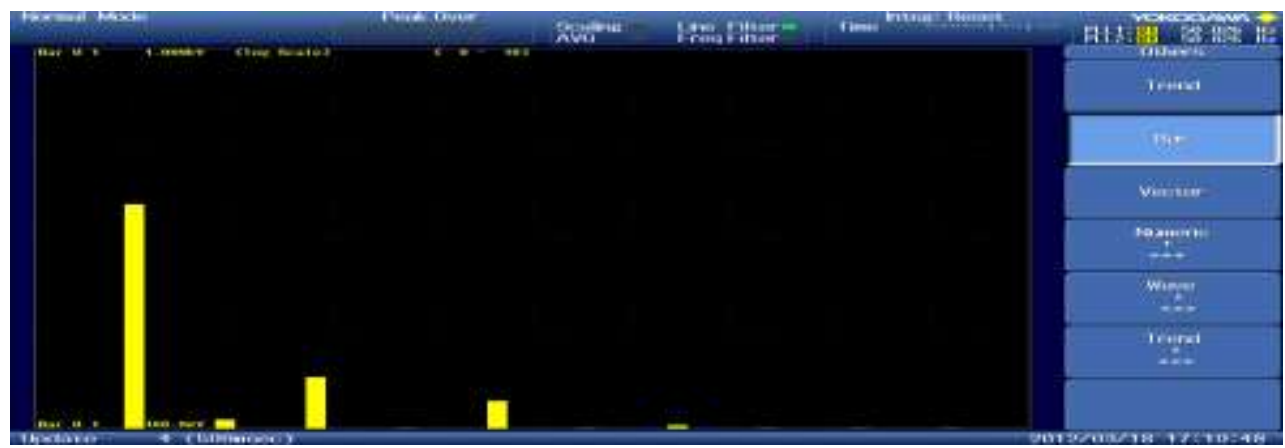

Figure 42. FFT plot for output voltage of PSPWM strategy for R-L load $\left(\mathrm{m}_{\mathrm{a}}=0.8\right.$ and $\left.\mathrm{m}_{\mathrm{f}}=63\right)$ 


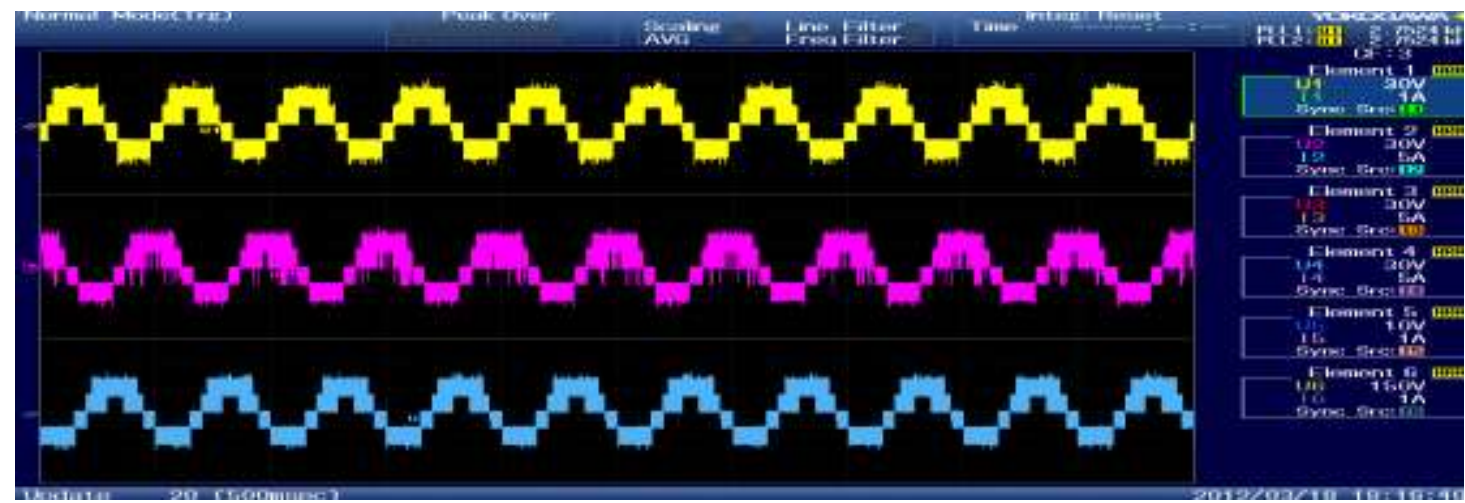

Figure 43. Output voltage generated by HYBRIDPWM strategy for R-L load. $\left(\mathrm{m}_{\mathrm{a}}=0.8\right.$ and $\left.\mathrm{m}_{\mathrm{f}}=63\right)$

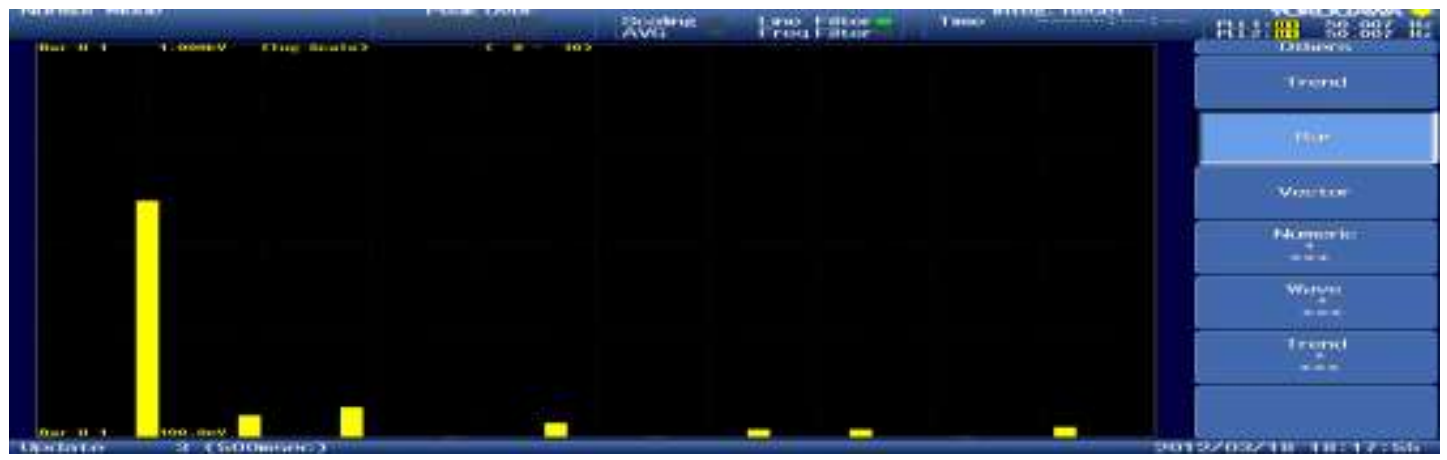

Figure 44. FFT plot of output voltage generated by HYBRIDPWM strategy for R-L load. $\left(\mathrm{m}_{\mathrm{a}}=0.8\right.$ and $\mathrm{m}_{\mathrm{f}}=63$ )

Table 6. \% THD for Different Modulation Indices for R-L Load (by Experiment)

\begin{tabular}{cccccc}
\hline $\mathrm{m}_{\mathrm{a}}$ & PD & POD & APOD & PS & HYBRID \\
& $3.15 \mathrm{KHz}$ & $3.15 \mathrm{KHz}$ & $3.15 \mathrm{KHz}$ & $3.15 \mathrm{KHz}$ & $3.15 \mathrm{KHz}$ \\
\hline 0.9 & 2.070 & 2.083 & 1.645 & 3.504 & 2.466 \\
0.85 & 2.568 & 2.337 & 2.219 & 1.802 & 2.508 \\
0.8 & 2.597 & 2.089 & 2.447 & 1.881 & 2.250 \\
0.75 & 1.781 & 1.908 & 2.425 & 2.070 & 2.445 \\
0.7 & 3.246 & 2.094 & 2.150 & 2.151 & 2.438 \\
0.65 & 2.603 & 2.306 & 2.329 & 2.143 & 2.772 \\
0.6 & 3.324 & 2.172 & 2.124 & 2.355 & 3.256 \\
\hline
\end{tabular}

Table 7. $\mathrm{V}_{\mathrm{rms}}$ (Fundamental) \% THD for Different Modulation Indices for R-L Load (by Experiment)

\begin{tabular}{cccccc}
\hline $\mathrm{m}_{\mathrm{a}}$ & PD & POD & APOD & PS & HYBRID \\
& $3.15 \mathrm{KHz}$ & $3.15 \mathrm{KHz}$ & $3.15 \mathrm{KHz}$ & $3.15 \mathrm{KHz}$ & 27.17 \\
\hline 0.9 & 26.33 & 26.49 & 26.42 & 24.38 & 26.32 \\
0.85 & 25.02 & 25.37 & 25.64 & 22.94 & 26.39 \\
0.8 & 23.69 & 23.96 & 23.95 & 21.87 & 24.87 \\
0.75 & 22.53 & 22.77 & 22.76 & 20.41 & 23.62 \\
0.7 & 21.36 & 21.26 & 20.06 & 19.08 & 22.15 \\
0.65 & 19.92 & 19.61 & 18.58 & 17.60 & 19.28 \\
0.6 & 18.31 & 18.33 & & & \\
\hline
\end{tabular}

\section{CONCLUSION}

Three phase multilevel inverter fed R-L load is simulated using the blocks of Simulink in this work. The simulation results are compared for two different switching frequencies. It is observed that HYBRID and PSPWM methods provide output with relative low distortion for low and high $\mathrm{f}_{\mathrm{c}}$ respectively and PODPWM and PSPWM are found to perform better since they provide relatively higher fundamental RMS output voltage for R-L load with $\mathrm{f}_{\mathrm{c}}=6$ and $3.15 \mathrm{KHz}$ respectively. If the switching frequencies are increased there is a slight decrease in the THD and slight increase in the Vrms. Table 1 displays the THD 
values for different PWM strategies for both $\mathrm{m}_{\mathrm{a}}$. Table 2 shows the Vrms values for various modulation indices. Table 3 shows the crest factor for both $\mathrm{m}_{\mathrm{a}}$. Table 4 display the form factor for different modulation indices. Table 5 provides the distortion factor. The experimental results shows PSPWM provide output with low distortion and HYBRID provide output with high fundamental RMS voltage for $\mathrm{f}_{\mathrm{c}}=3.15 \mathrm{KHz}$. The experimental results were obtained only for $\mathrm{f}_{\mathrm{c}}=3.15 \mathrm{KHz}$.

\section{REFERENCES}

[1] Rajesh Gupta, et al., "Switching Charaterization of Cascaded Multilevel Inverter-Controlled Systems", IEEE Trans. on Indust. Electr., vol.55, no.3, pp 1047-1058, March 2008.

[2] P.Palanivel and Dash, "Implementation of THD and Output Voltage of Three Phase Cascaded Multilevel Inverter Using Multicarrier Pulse Width Modulation Techniques", IEEE Conf. ICSET 2010, 6-9 Dec 2010, Kandy, Sri Lanka.

[3] Rajesh Gupta, et al., "Multiband Hysteresis Modulation and Switching Characterization for Sliding Mode Controlled Cascaded Multilevel Inverter", IEEE Trans. on Indust. Electr., vol.57, no.7, 2010, pp 2344-2353.

[4] H.Ghoreishy, et al., "Reducing Common Mode Voltage and Power Dissipation in Cascaded Multilevel Inverters with Flexible DC Sources", $1^{\text {st }}$ Power Electronics and Drives \& Technologies Conference, 2010, pp 175-179.

[5] J. Mariuz Malinowski, et al., "A Survey on Cascaded Multilevel Inverters”, IEEE Trans. on Indust. Electr., vol.57, pp 2197- 2206, 2010.

[6] Zhong Du, et al., "Fundamental Frequency Switching Strategies of a Seven Level Hybrid Cascaded H-Bridge Multilevel Inverter", IEEE Trans. on Power Electr., vol.24, no.1, pp 25-33, 2009.

[7] Remus Teodorescu, et al., "Multilevel Inverter by Cascaded Industrial VSI", IEEE Trans. on Indust. Electr., vol.49, no.4, pp.832-834, 2002.

[8] A.Keith, et al., "Control of Cascaded Multilevel Inverter," IEEE Trans. on Power Electr., vol.19, no.3, pp.732-738, 2004.

[9] K.Deepa, et al., "Harmonic Analysis of a Modified Cascaded Multilevel Inverter", ${ }^{\text {st }}$ International Conference on Electrical systems, 2011, pp.93-97.

[10] A.B.Diorge, et al., "Comparison of Neutral Point Clamped, Symmetrical and Hybrid Asymmetrical Multilevel Inverters”, IEEE Trans. on Industr. Electr., vol.57, no.7, pp.2297-2306, 2010.

[11] Youheihinago and Hirotaka Koizumi, "A Single Phase Multilevel Inverter Using Switched Series/Parallel DC Voltage Sources", IEEE Trans. on Industr. Electr., vol.57, no.8, pp.1643-265, 2010.

[12] C.Risnidar, et al., "Influence of Harmonics in Laboratory due to Nonlinear Loads", International Journal of Power Electronics and Drive System, vol. 2, no. 2, pp. 219-224, 2012.

[13] Mohammad Jamil, "Comparison of Multilevel Inverters for the Reduction of Common Mode Voltage ", International Journal of Power Electronics and Drive System, vol. 3, no. 2, pp. 170-178, 2013.

[14] Y.R.Manjunatha and B.A.Anand, "Multilevel DC Link Inverter with Reduced Switches and Batteries", International Journal of Power Electronics and Drive System, vol. 4, no. 3, pp. 299-307, 2014.

[15] C.R.Balamurugan et al., "New Bipolar Hybrid Carrier PWM Strategies for Symmetrical Multi Level Inverter", TELKOMIKA Indonesian Journal of Electrical Engineering, ISSN No. 2302-4046, vol. 14, no. 2, pp. 228-240, 2015.

[16] C.R.Balamurugan et al, "Simulation and dSPACE Based Implementation of Various PWM Strategies for A New H-Type FCMLI Topology”, International Journal of Power Electronics and Drive System, vol. 6 , no. 3, pp. 615$624,2015$.

\section{BIOGRAPHIES OF AUTHORS}

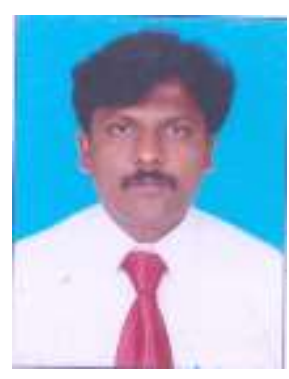

Dr. C.R.Balamurugan was born in 1978 in Kumbakonam. He has obtained B.E (Electrical and Electronics) and M.E (Power Electronics and Drives) degrees in 2000 and 2005 respectively from Arunai Engineering College, Tiruvannamalai and Sathyabama University, Chennai. He has been working in the teaching field for about 10 years. His areas of interest include power electronics, electrical machines and solar energy systems. He has 30 publications in international journals. His research papers 25 have been presented in various/IEEE international/national conferences. Currently, he is working as Assistant Professor in the Department of EEE, Arunai Engineering College, Tiruvannamalai. He is a life member of Instrument Society of India and Indian Society for Technical Education. Contact number- +91-9894522351. Email:crbalain2010@gmail.com. 


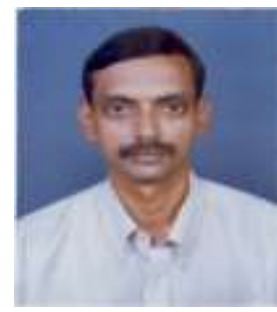
Electronics) and M.E (Power Systems) degrees in 1978 and 1984 respectively from Annamalai University securing distinction and then Ph.D in Power Electronics from Anna University, Chennai in 2003. He is currently Professor and Head of Instrumentation Engineering Department at Annamalai University where he has put in 31 years of service. He produced eight Ph.Ds and presently guiding eight Ph.D Scholars and so far guided eighty M.E students. His research papers 66 have been presented in various/IEEE international/national conferences in Mexico, Virginia, Hong Kong, Malaysia, India, Singapore and Korea. He has 20 publications in national journals and 43 in international journals. His research interests are in modeling and control of DC-DC converters and multiple connected power electronic converters, control of permanent magnet brushless DC motor, embedded control for multilevel inverters and matrix converters etc. He is a life member of Instrument Society of India and Indian Society for Technical Education. Contact number- +91-9443185211. Email: spn_annamalai @ rediffmail.com.

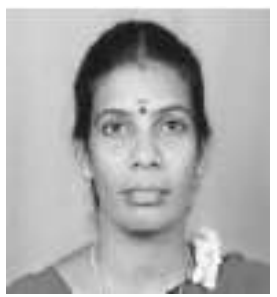

Dr. T.S.Anandhi obtained the B.E. (Electronics and Instrumentation), M.E (Process Control and Instrumentation) and Ph.D degrees from Annamalai University She is presently a Reader in the Department of Instrumentation Engineering, Annamalai University where she has put in a total service of 16 years. Her research interests are in modeling and control of multiple connected DCDC converters and multilevel inverters.

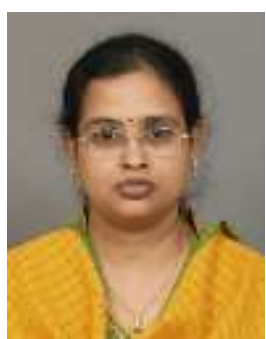

Dr. B.Shanthi was born in 1970 in Chidambaram. She has obtained B.E (Electronics and Instrumentation) and M.Tech (Instrument Technology) from Annamalai University and Indian Institute of Science, Bangalore in 1991 and 1998 respectively. She obtained her Ph.D in Power Electronics from Annamalai University in 2009. She is presently a Professor in Central Instrumentation Service Laboratory of Annamalai University where she has put in a total service of 22 years since 1992.Her research papers (30) have been presented in various / IEEE international/national conferences. She has 3 publications in national journal and 35 in international journals. Her areas of interest are: modeling, simulation and intelligent control for inverters. Contact number- +91-9443185211. Email: shancisl@ gmail. com. 